\title{
Climate diagnostics of three major drought events in the Amazon and illustrations of their seasonal precipitation predictions
}

\author{
Caio A. S. Coelho, ${ }^{\text {a* }}$ Iracema A. F. Cavalcanti, ${ }^{a}$ Simone M. S. Costa, ${ }^{\text {a }}$ Saulo R. Freitas, ${ }^{\text {a }}$ Ester R. Ito, ${ }^{\text {a }}$ \\ Giovana Luz, ${ }^{\mathrm{a}}$ Ariane F. Santos, ${ }^{\mathrm{a}}$ Carlos A. Nobre, ${ }^{\mathrm{b}}$ José A. Marengo ${ }^{\mathrm{b}}$ and Alexandre B. Pezza ${ }^{\mathrm{c}}$ \\ a Centro de Previsão de Tempo e Estudos Climáticos, Instituto Nacional de Pesquisas Espaciais, Cachoeira Paulista, SP, Brazil \\ b Centro de Ciência do Sistema Terrestre, Instituto Nacional de Pesquisas Espaciais, São José dos Campos, SP, Brazil \\ c School of Earth Sciences, The University of Melbourne, Victoria, Australia
}

\begin{abstract}
The Amazon has a well-defined wet austral summer monsoon and dry winter monsoon precipitation regime and experienced a sequence of drought events in the last 13 years. This study performs a comparative assessment of observed and predicted climate conditions during the three most recent drought events in the Amazon, in 1997-1998, 2004-2005 and 2009-2010, with emphasis on how these events affected the regional monsoon-like precipitation regime. A century long Negro River level time series at Manaus is investigated, applying extreme values theory for estimating return periods of these major drought events. Possible teleconnections of river levels at Manaus and sea surface temperature at remote regions are explored. Large scale oceanic and atmospheric conditions are investigated to highlight the mechanisms associated with the observed drought conditions, particularly during the dry monsoon season. Satellite estimates are used for diagnosing biomass burning aerosol and discuss possible contributions to the observed precipitation deficits in the 2005 and 2010 drought events during the dry monsoon season. The study is concluded with an analysis of the performance of seasonal precipitation predictions for the dry monsoon seasons of July to September 1998, 2005 and 2010 produced with the operational seasonal prediction system used at the Center for Weather Forecasts and Climate Studies (CPTEC) of the Brazilian National Institute for Space Research (INPE). This system was capable of producing 1 month in advance drought warning for the three investigated events, relevant for helping the government and local population make decisions for reducing drought impacts in the Amazon region. Copyright (c) 2012 Royal Meteorological Society
\end{abstract}

KEY WORDS Amazon droughts; monsoon precipitation regime; extreme river levels; teleconnections; aerosol; seasonal prediction

Received 28 November 2011; Revised 12 March 2012; Accepted 5 April 2012

\section{Introduction}

The Amazon region, in tropical South America, has a well defined monsoon-like precipitation regime with a wet season during the austral summer months and a dry season during the austral winter months (Jones and Carvalho, 2002). On the 24 October 2010, the level of the Negro River at Manaus reached its lowest value $(1363 \mathrm{~cm})$ since records began in 1903. Similar river levels $(1364 \mathrm{~cm})$ had previously been recorded on the 30 and 31 October 1963. Both events were linked to meteorological drought conditions (i.e. precipitation deficit of at least $100 \mathrm{~mm}$ per month mainly during the wet summer monsoon months) over the Amazon region. During these events navigation is severely affected, causing shortage of food and transportation problems. Hydroelectricity power generation is also reduced in the region and the abnormally dry conditions favour the spread of fires that affect biodiversity. In addition, the smoke generated by the fires seriously affects air transportation and health. Drought impacts therefore affect directly the livelihood of the Amazon population.

\footnotetext{
* Correspondence to: C. A. S. Coelho, Centro de Previsão de Tempo e Estudos Climáticos (CPTEC), Instituto Nacional de Pesquisas Espaciais (INPE), Rodovia Presidente Dutra, Km 40, SP-RJ, Cachoeira Paulista
} 12630, SP, Brazil. E-mail: caio.coelho@cptec.inpe.br
The Amazon has experienced three major drought events during the last 13 years, in 1997-1998, 2004-2005 and 2009-2010. This apparent frequency increase of drought events in the last decade caught the attention of scientists not only because of the impacts on local populations but also because Amazon droughts can have important impacts on global climate (Marengo et al., 2008, 2011). Lewis et al. (2011) have compared the two most recent drought events in the Amazon in 2005 and 2010 using a measure of drought intensity that correlates with tree mortality. The authors highlighted the impact of tree mortality on carbon dioxide release to the atmosphere as opposed to carbon dioxide sequestration performed by healthy trees. Their results suggest that if drought events continue, the era of intact Amazon forest buffering the increase in atmospheric carbon dioxide may have passed.

Droughts in the Amazon have previously been documented (see Marengo et al., 2008 and references therein) to be associated with: (1) the occurrence of intense El Niño events, (2) anomalous warming of sea surface temperatures in the tropical North Atlantic during the austral winter-spring, or (3) both. The present study aims to perform a comparative assessment of the observed and predicted climate conditions during the three most recent drought events in the Amazon with particular emphasis on how these events affect the regional monsoon-like precipitation regime. Such a detailed comparative assessment is of relevance for understanding how drought events evolve and how well these events are predicted. To the authors' knowledge 
this is the first applied analysis combining climate diagnostics and climate prediction illustrations for these three drought events in the Amazon. The study assesses the ability of the Center for Weather Forecasts and Climate Studies (CPTEC) atmospheric global general circulation model (AGCM, Cavalcanti et al., 2002; Marengo et al., 2003) in predicting drought conditions in the Amazon. The diagnostic observational assessment is performed in terms of Negro River levels recorded at Manaus $\left(3.11^{\circ} \mathrm{S}, 60.01^{\circ} \mathrm{W}\right.$ ), sea surface temperatures (Reynolds et al., 2002), precipitation (Huffman et al., 2007) and aerosol (Remer et al., 2005) over the Amazon. The study has a strong applied focus relevant for climate services (i.e. monitoring and prediction practices) with direct societal impacts. Novel applied aspects addressed in this study include an analysis of extraordinary low river levels applying extreme value theory to a century long Negro River level time series, the investigation of teleconnections between Negro River level and climate conditions in remote ocean regions also based on a near centennial record, and the diagnostics of aerosol conditions over the Amazon during the most recently observed drought year using proxy information obtained from a meteorological satellite.

The manuscript is organized as follows. Section 2 presents a detailed analysis of Negro River level historical records applying extreme value theory to monthly mean river levels, putting in perspective those events when river levels fell below a pre-defined low threshold associated with drought events. Section 3 explores teleconnections between Negro River level and climate conditions in remote ocean regions contributing to changes in the monsoon-like precipitation regime over the Amazon. Section 3 also presents a detailed time-evolving analysis of global sea surface temperature and precipitation patterns over the Amazon during the three most recent drought events in the Amazon, highlighting how drought conditions affected the regional monsoon-like precipitation regime. Section 4 presents an analysis of large-scale circulation patterns associated with drought conditions observed during the July to September seasons of 1998, 2005 and 2010. Section 5 describes the time evolution of aerosols over the Amazon during the two most recent drought events (2005 and 2010), suggesting possible mechanisms by which aerosol might contribute to reinforce drought conditions and discussing how late wet monsoon season onsets or prolonged dry monsoon season periods might influence biomass burning aerosol concentration. Section 6 presents a performance assessment of seasonal precipitation predictions for July to September 1998, 2005 and 2010 produced by CPTEC/AGCM in the previous June. Section 7 concludes with a summary of the main findings.

\section{Negro River level historical records: extreme value analysis}

The gauging site at Manaus, located in the Brazilian state of Amazonas, northern Brazil, has one of the best river level records for historical climate analysis, starting in 1903 up to the present. Figure 1 shows the Negro River level annual cycle given by the monthly mean river level at Manaus. The solid thick line represents the long term 1903-2010 monthly mean annual cycle (i.e. climatology). This figure reveals that climatologically the river reaches maximum levels during the period May to July and minimum levels during the period October to December, illustrating the existence of a well defined monsoon-like regime in the region with high levels following the wet austral summer monsoon season and low levels following the dry austral winter monsoon season. Negro
River levels at Manaus reflect the influence of its basin, which extends over northern Amazon and the Solimões River, whose basin extends over southern and western Amazonia.

The remaining three lines of Figure 1 show the observed monthly mean river levels from June 1997 to December 1998 (solid thin line), from June 2004 to December 2005 (dotted line) and from June 2009 to December 2010 (dashed line). These three events presented well below climatology river levels, particularly during October and November 1998, 2005 and 2010, highlighting the drought effect observed in this region. The main differences between these events are observed in the previous year. For the 1997-1998 event, river levels in October and November 1997 were well below climatology, reaching near climatology conditions during June to August 1998, and returning to below climatology conditions after August 1998. For the 2004-2005 event river levels in October and November 2004 were above climatology, reaching near climatology levels in January and February 2005 and above climatology from March to June 2005. After that, below climatology conditions started to be observed. In the 2009-2010 event, river levels in November and December 2009 were below climatology, remaining near climatology levels until June 2010, with the reestablishment of below climatology conditions after July 2010.

Figure 2 shows monthly mean Negro River level time series for the period 1903-2010 for all 12 months of the year. In accordance with the climatological feature illustrated in Figure 1 (solid thick line), Figure 2 shows a time evolution with October (Figure 2(j)), November (Figure 2(k)) and December (Figure 2(1)) representing the 3 months when river levels reach lowest values following the dry austral winter monsoon season. January to April (Figure 2(a)-(d)) represent a transitional period between low river levels in the period from October to December (Figure 2(j)-(1)) and high river levels in the period from May to August (Figure 2(e)-(h)) following the wet austral summer monsoon season. Drought effects are most noticeable in the period of low river records (October to December) and therefore this period is investigated in more details in the present study. The dashed horizontal lines in Figure 2 are the 1903-2010 long term means, which for October (Figure 2(j)), November (Figure 2(k)) and December (Figure 2(l)) are 1891.8, 1857.2 and $1973.6 \mathrm{~cm}$, respectively. As illustrated in Figure 1 the minimum mean river level is observed in November. The smooth solid blue curves are the long term trends that represent decadal variability

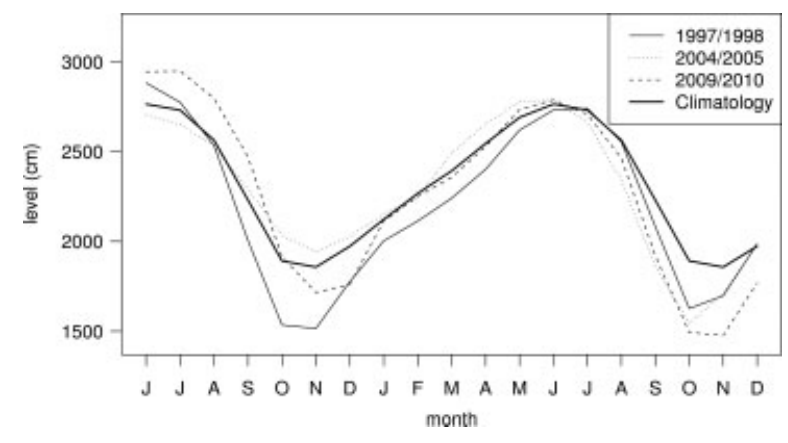

Figure 1. Negro river level annual cycle $(\mathrm{cm})$ given by the monthly mean river level from June to December. The solid thick line represents the long term 1903-2010 monthly mean annual cycle. The solid thin line is the observed monthly mean river level from June 1997 to December 1998. The dotted line is the observed monthly mean river level from June 2004 to December 2005. The dashed line is the observed monthly mean river level from June 2009 to December 2010. 

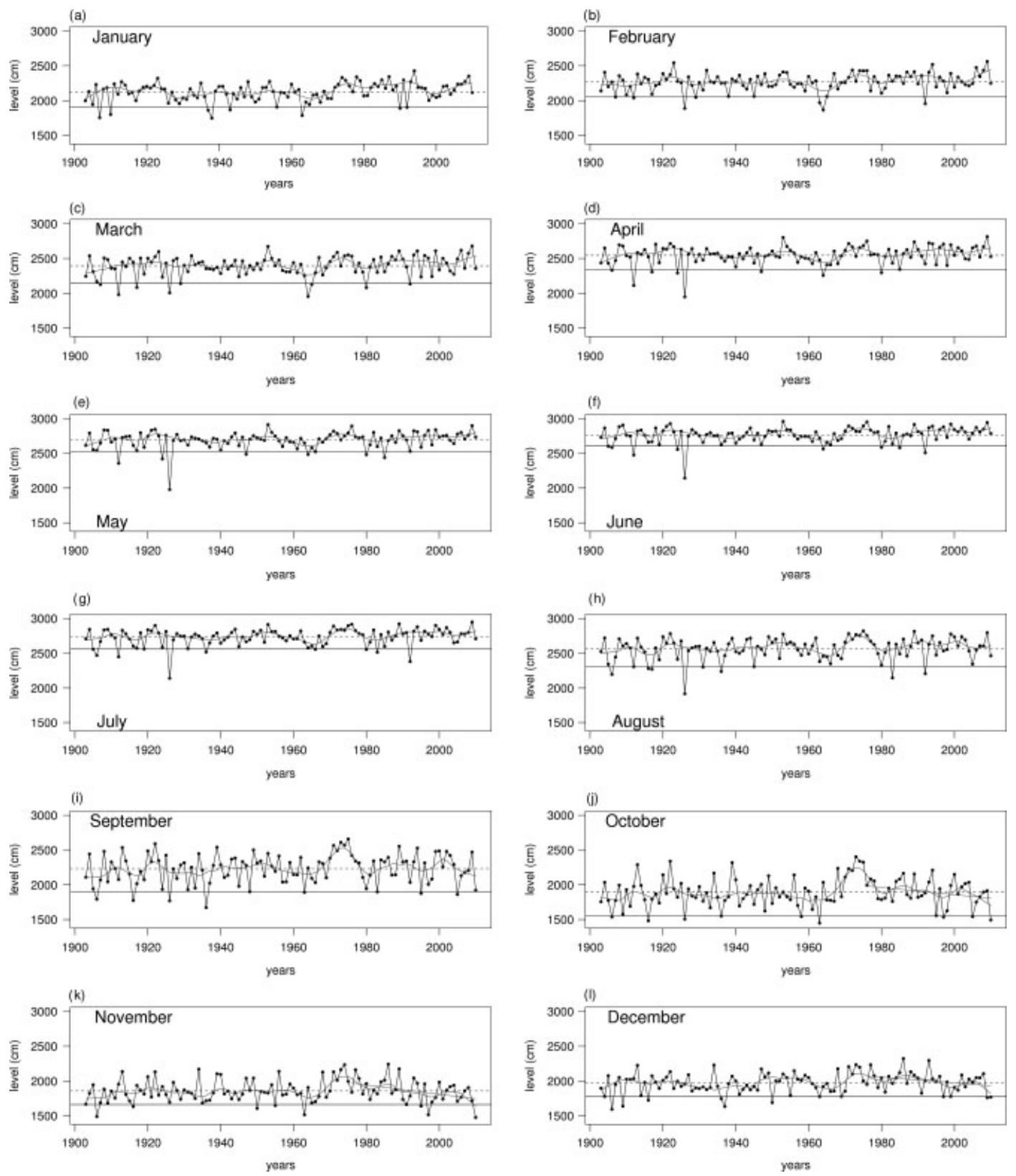

Figure 2. Monthly (January to December, panels (a) to (1)) mean Negro River level (cm) time series for the period 1903-2010. The dashed horizontal lines are the 1903-2010 long term means. The smooth solid blue curves are the long term trends that represent decadal variability. The horizontal solid lines are the $7.5^{\text {th }}$ quantiles of monthly mean river level values (black dots). The red solid lines in panels (j) to (l) are the 1976-2010 linear trends for October, November and December. The $p$-values for the null hypothesis of no trend are $0.10,0.02$ and 0.07 for October, November and December, respectively.

estimated with a local polynomial fit with a sliding window of 10 years. Focusing on the low river level months (October to December) two features are highlighted by these curves (Figure 1(j)-(l)): an increase in river levels in the mid1970s when global climate conditions were influenced by a long La Niña period (1973-1976), contributing to abnormal precipitation in tropical South America, and a decrease in river levels in the last observed decade due to a combination of warmer than normal conditions in the tropical North Atlantic and the manifestation of El Niño in the tropical Pacific, both contributing to precipitation deficit in tropical South America, as discussed in Section 3.

The horizontal solid lines in Figure 2 are the $7.5^{\text {th }}$ quantiles of monthly mean river level values (black dots), which divide the record in two halves $(7.5 \%$ below the horizontal solid lines and $92.5 \%$ above the horizontal solid lines). These quantile values are 1551.1, 1662.5 and $1775.9 \mathrm{~cm}$ for October (Figure 2(j)), November (Figure 2(k)) and December (Figure 2(l)), respectively. Extreme river level events can be defined as those events with river level values observed below these quantiles and illustrate extremes that recur on average once every 13.33 years. Extreme value theory using the peaks-over-threshold approach (see Coles, 2001, Chapter 4) can be used to study extreme events. This approach consists in defining a suitably high (or low) threshold for selecting a subset of excess values above the threshold (or deficit values below the threshold) from the data sample to infer the extreme behaviour of the underlying process that generated the data (Coles, 2001). In this study the interest 
Table 1. October (left), November (central) and December (right) observed river levels, deficits given by the difference between the observed river level for a particular month and year and the corresponding $7.5^{\text {th }}$ quantile of the monthly river level distribution, and return period estimates according to a generalized Pareto distribution fit to all deficits presented in this table.

\begin{tabular}{|c|c|c|c|c|c|c|c|c|c|c|c|}
\hline \multicolumn{4}{|c|}{ October } & \multicolumn{4}{|c|}{ November } & \multicolumn{4}{|c|}{ December } \\
\hline Year & $\begin{array}{c}\text { Level } \\
(\mathrm{cm})\end{array}$ & $\begin{array}{c}\text { Deficit } \\
(\mathrm{cm})\end{array}$ & $\begin{array}{l}\text { Return } \\
\text { period } \\
\text { (years) }\end{array}$ & Year & $\begin{array}{c}\text { Level } \\
(\mathrm{cm})\end{array}$ & $\begin{array}{c}\text { Deficit } \\
(\mathrm{cm})\end{array}$ & $\begin{array}{l}\text { Return } \\
\text { period } \\
\text { (years) }\end{array}$ & Year & $\begin{array}{c}\text { Level } \\
(\mathrm{cm})\end{array}$ & $\begin{array}{l}\text { Deficit } \\
(\mathrm{cm})\end{array}$ & $\begin{array}{l}\text { Return } \\
\text { period } \\
\text { (years) }\end{array}$ \\
\hline 1963 & 1449.5 & -101.6 & 4.38 & 2010 & 1476.6 & -185.9 & 25.30 & 1906 & 1592.6 & -183.3 & 23.69 \\
\hline 1916 & 1482.8 & -68.3 & 2.55 & 1906 & 1488.8 & -173.7 & 18.75 & 1937 & 1633.6 & -142.3 & 9.38 \\
\hline 2010 & 1493.7 & -57.4 & 2.17 & 1963 & 1514.8 & -147.7 & 10.48 & 1909 & 1637.7 & -138.2 & 8.63 \\
\hline 1926 & 1506.0 & -45.1 & 1.82 & 1997 & 1515.4 & -147.2 & 10.37 & 1950 & 1690.2 & -85.6 & 3.35 \\
\hline 1997 & 1535.3 & -15.8 & 1.22 & 1950 & 1606.3 & -56.2 & 2.13 & 1916 & 1723.3 & -52.6 & 2.02 \\
\hline 1906 & 1537.2 & -13.9 & 1.19 & 1916 & 1631.7 & -30.8 & 1.49 & 1936 & 1745.3 & -30.6 & 1.49 \\
\hline 2005 & 1542.6 & -8.5 & 1.11 & 1995 & 1639.5 & -23.0 & 1.34 & 2009 & 1761.0 & -14.8 & 1.21 \\
\hline 1958 & 1543.5 & -7.6 & 1.10 & 1955 & 1647.4 & -15.2 & 1.21 & 2010 & 1768.9 & -7.0 & 1.09 \\
\hline 1936 & 1551.0 & -0.1 & 1.00 & 1991 & 1662.4 & -0.1 & 1.00 & 1997 & 1775.9 & -0.01 & 1.00 \\
\hline
\end{tabular}

is on low river level values associated with droughts and therefore the subset consists of deficits below the threshold. These deficits are computed as the difference between the monthly mean river level value of each year (black dots in Figure 2) and the $7.5^{\text {th }}$ quantile value (horizontal solid line in Figure 2).

The choice of threshold is often a compromise between having small enough values to represent events in the tail of the distribution, yet also having a sufficient number of deficit events to obtain a reliable fit. Therefore, deficits below the threshold do not always have to be in the far tail of the distribution and so should not be referred to as simple extreme events. In other words, moderately rare events (e.g. deficits below the $7.5^{\text {th }}$ quantile) can sometimes be useful to make inference about extreme behaviour. A deficit below a threshold defines a value that can be used to infer the properties of the whole continuum of events having small values.

Table 1 shows the observed river level and the corresponding deficits for all extreme events below the $7.5^{\text {th }}$ quantile values for October, November and December. A total of 27 extreme events ( 9 for each month) have been identified. The sample of 27 deficits of Table 1 is used for inferring extreme behaviour of river levels by fitting a generalized Pareto distribution (Coles, 2001, chapter 4) to this sample for the following reason. Three different thresholds are used for defining deficits to account for calendar month variations in river level records. By examining the river level time series in Figure 2 for October (Figure 2(j) and (l)), November (Figure 2(k)) and December (Figure 2(1)) and also the climatological river level curve (thick solid line in Figure 1), it is noticeable that these 3 months have common river level statistical characteristics in terms of their long term means, range of recorded values and deficits below the $7.5^{\text {th }}$ quantiles. This is the period when low river levels are recorded following the dry austral winter monsoon season. As only 9 deficits are depicted for each of these 3 months, in order to increase the robustness of the extreme value statistical analysis by increasing the sample size for the generalized Pareto distribution fitting, and due to the similarities in river level statistical characteristics during the low river level period, all 27 deficits for the 3 months are analysed as belonging to the same statistical distribution. The generalized Pareto distribution scale $(\sigma=80.83 \mathrm{~cm})$ and shape $(\xi=-0.22)$ parameters are estimated using the maximum likelihood method (Coles, 2001, Section 2.6.3). The scale parameter provides information about the variability of deficits. The shape parameter provides information about the form (or fatness) of the tail of the distribution of deficits. The negative estimate for the shape parameter indicates that the distribution of deficits has a lower bound given by $\sigma / \xi$ and equals $-360.69 \mathrm{~cm}$. In other words, this lower boundary is the estimate of the lowest possible deficit value given this sample of 27 deficits.

In order to check the goodness of the generalized Pareto distribution fit to these 27 deficits and also assess if only 27 values were enough to represent the tail of the distribution, the empirical and fitted distributions were plotted (not shown) and also Kolmogorov-Smirnov (KS) test statistics were computed. This is a test of the null hypothesis that the true distribution function of river level deficits is a generalized Pareto distribution. The obtained $p$-value for the KS statistics was 0.29 , indicating a high probability $(29 \%)$ of rejecting the null hypothesis in favour of the alternative hypothesis that the true distribution function of river level deficits is different from a generalized Pareto distribution when the null hypothesis could be true. With such a large $p$-value the null hypothesis cannot be rejected in favour of the alternative hypothesis. The result of this statistical test and the examination of the fitted and empirical distributions indicated that the generalized Pareto distribution fit represents well the 27 deficit values here investigated and shows that the $7.5^{\text {th }}$ quantile was a sensible choice for investigating extreme low river levels.

By inverting the generalized Pareto distribution it is possible to estimate the return period of each extreme event. The return period is the frequency with which one would expect, on average, a given value (e.g., a deficit of $101.6 \mathrm{~cm}$ as observed in October 1963) to recur. Table 1 shows the return periods for each of the 27 observed deficits of the October, November and December monthly river levels. The 2010 event appears as the third most extreme event in October, with a return period estimate of 2.17 years, with a $90 \%$ confidence interval of 2.68 to 8.00 years estimated using a bootstrap resampling procedure (Davison and Hinkley, 1997) computed for illustrating typical uncertainties. The 2010 event also appears as the most extreme event in November, with a return period estimate of 25.30 years, with a $90 \%$ confidence interval of 11.22 to 588.57 years, and the $8^{\text {th }}$ most extreme event in December, with a return period estimate of 1.09 years. The 2005 event appears as the $7^{\text {th }}$ most extreme event in October but is not identified as an extreme event in November and December. The 1997 event appears as the $5^{\text {th }}$ most extreme event in October, with a return period estimate of 1.22 years, 
with a $90 \%$ confidence interval of 1.12 to 1.34 years, the fourth most extreme event in November, with a return period estimate of 10.37 years, with a $90 \%$ confidence interval of 5.51 to 51.57 years, and the $9^{\text {th }}$ most extreme event in December, with a return period estimate of 1 year.

\section{Teleconnection analysis, global sea surface temperature and precipitation patterns over the Amazon}

In order to explore possible teleconnections between the Negro River level at Manaus and climate conditions in remote regions, Figure 3 shows simultaneous correlation maps between Negro monthly mean river levels time series (Figure 2) and sea surface temperature (Rayner et al., 2003) for all 12 months of the year for the near centennial period 1903-2010. Negative river level trends are observed after 1976, particularly for October, November and December, and are illustrated with the red lines in Figure 2(j)-(l). In order to isolate the effect of inter-annual climate variability from the effect of linear time trends both river level and sea surface temperature time series were detrended prior to computing correlation co-efficients. Only correlation values statistically significant at the 5\% level are shown in Figure 3. The tropical North Atlantic (as illustrated with the box over the area $5-25^{\circ} \mathrm{N}, 20-70^{\circ} \mathrm{W}$ ) appears as the region with most consistent negative association between river levels and sea surface temperatures during nearly all months (except May, Figure 3(e)), indicating that above (below) normal sea surface temperature in the tropical North Atlantic are consistently associated with reduced (increased) river levels. The strongest negative association in the tropical North Atlantic with Negro River levels is observed in the second half of the year between July (Figure 3(g)) and December (Figure 3(1)). The Niño-3.4 region (as illustrated with the box over the area $5-5^{\circ} \mathrm{S}, 120-170^{\circ} \mathrm{W}$ ) also shows negative association with river levels during February (Figure 3(b)), March (Figure 3(c)) and April (Figure 3(d)), indicating that above (below) normal sea surface temperature in the equatorial Pacific typical of El Niño (La Niña) conditions are consistently associated with reduced (increased) river levels.
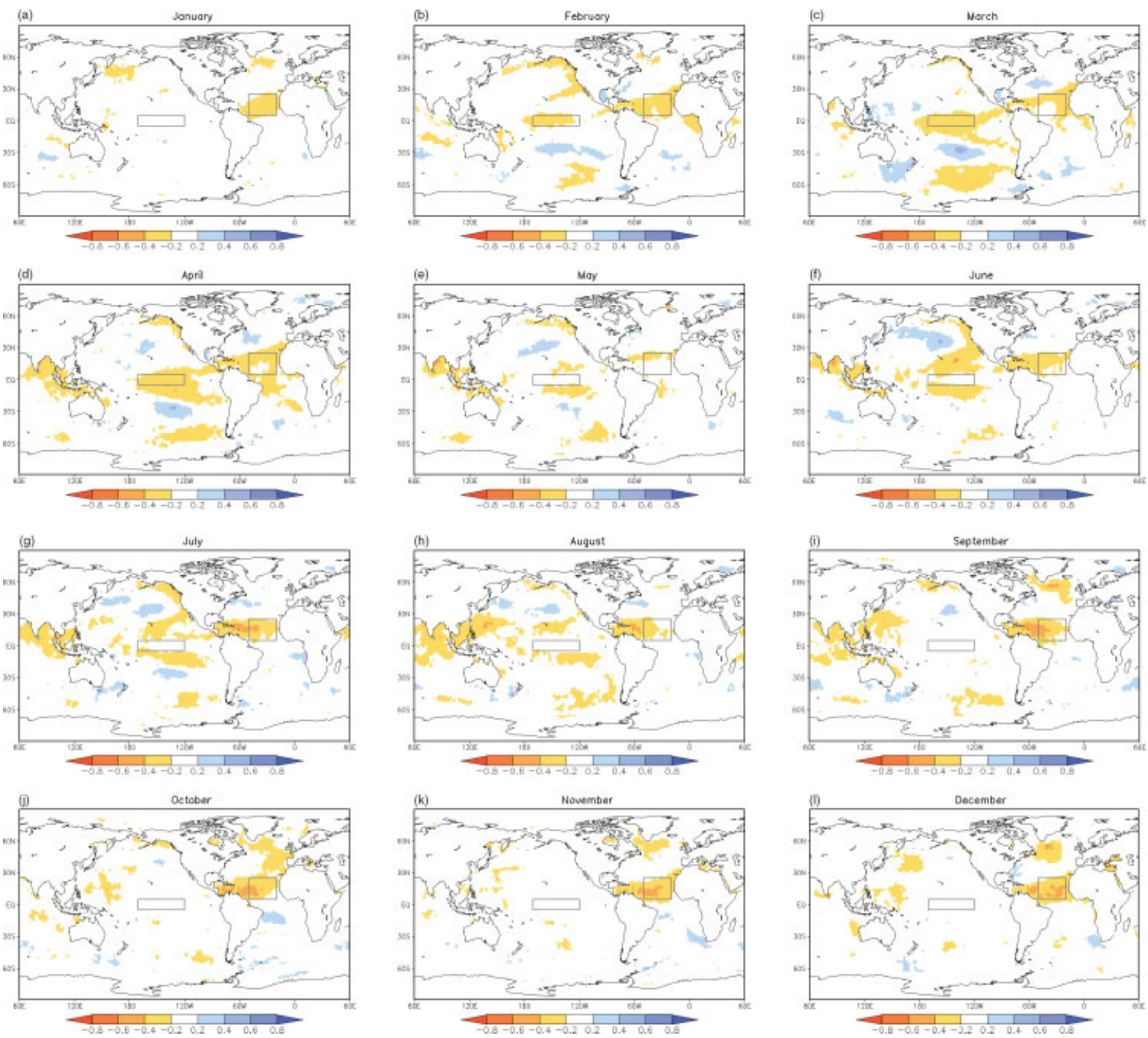

Figure 3. Teleconnection maps given by the simultaneous correlation for the period 1903-2010 between Negro monthly mean river levels and sea surface temperature (Rayner et al., 2003) for all 12 months of the years (panels (a) to (1)). Both linear time trends in river level and sea surface temperature time series were removed prior to computing correlation co-efficients. Statistically significant correlation values at the $5 \%$ level are shaded. The boxes shown in each panel delimitate the Niño-3.4 region $\left(5^{\circ} \mathrm{N}\right.$ to $\left.5^{\circ} \mathrm{S}, 120-170^{\circ} \mathrm{W}\right)$ in the Pacific and the tropical north Atlantic region $\left(5-25^{\circ} \mathrm{N}, 20-70^{\circ} \mathrm{W}\right)$. 
(a) Sea surface temperature anomaly DJF 1997/1998

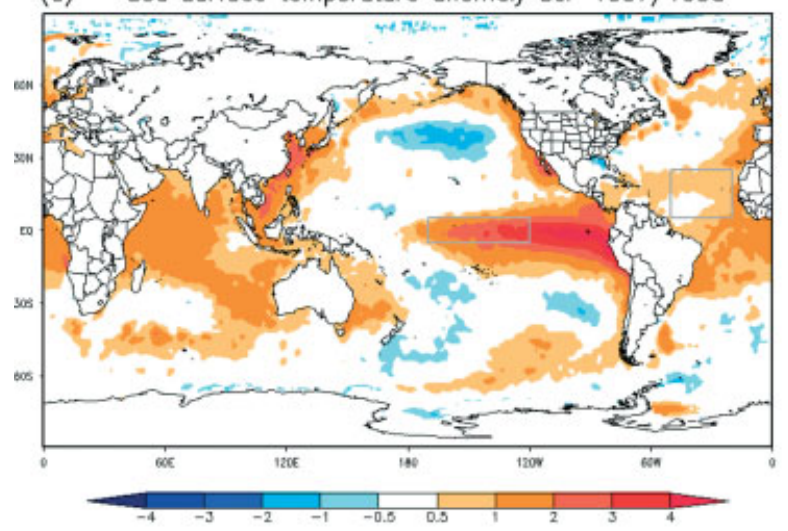

(c) Sea surface temperature anomaly JJA 1998

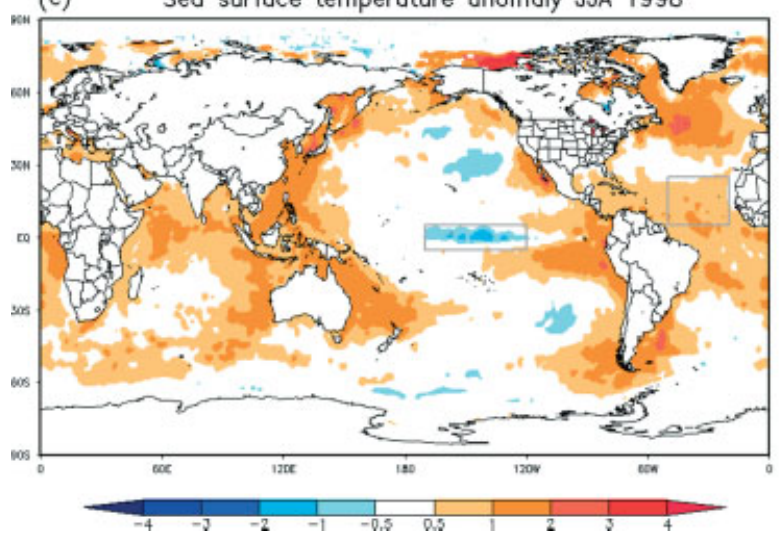

(b) Sea surfoce temperature anomay MAM 1998

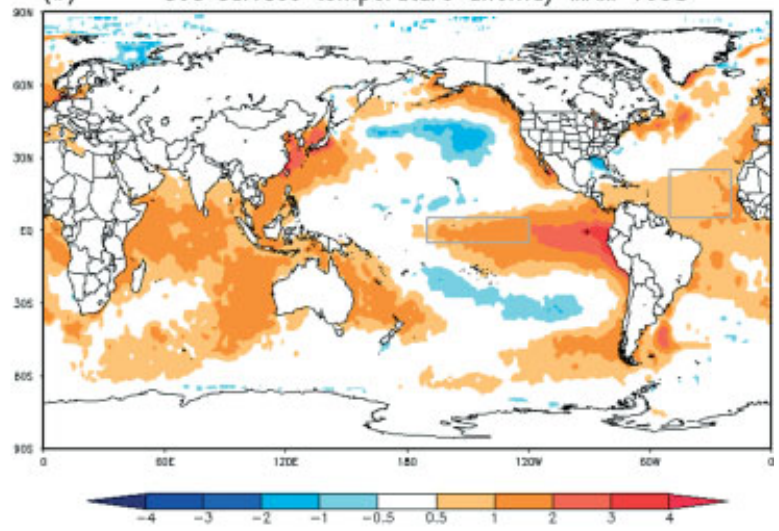

(d)

Sea surface temperature anomaly SON 1998

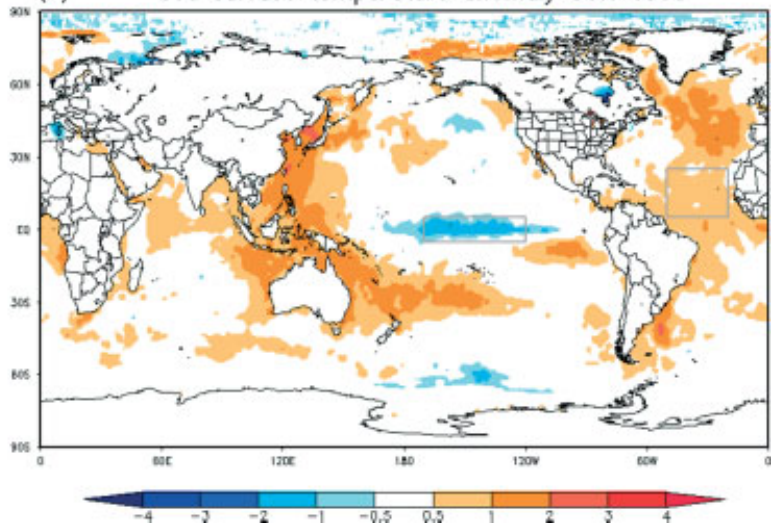

Figure 4. Observed sea surface temperature (Rayner et al., 2003) anomalies during (a) December, January, February 1997-1998, (b) March, April, May 1998, (c) June, July, August 1998 and (d) September, October, November 1998. Anomalies are computed with respect to the 1903-1996 long term mean (climatology). The boxes shown in each panel delimit the Niño-3.4 region $\left(5^{\circ} \mathrm{N}\right.$ to $\left.5^{\circ} \mathrm{S}, 120-170^{\circ} \mathrm{W}\right)$ in the Pacific and the tropical north Atlantic region $\left(5-25^{\circ} \mathrm{N}, 20-70^{\circ} \mathrm{W}\right)$.

Sea surface temperatures are considered one of the main drivers of climate variability, particularly in the tropics (Charney and Shukla, 1981; Brankovic et al., 1994). Below is presented an analysis of sea surface temperature and the associated precipitation patterns over the Amazon for the drought events of 1997-1998, 2004-2005 and 2009-2010, illustrating how the monsoon-like regime was affected by drought conditions. The atmospheric circulation mechanisms leading to the observed precipitation patterns will be discussed in Section 4.

Figure 4 shows the observed sea surface temperature anomalies during December to February 1997-1998 (Figure 4(a)), March to May 1998 (Figure 4(b)), June to August 1998 (Figure 4(c)) and September to November 1998 (Figure 4(d)). By the end of 1997 the tropical Pacific was experiencing the effects of the strongest El Niño event ever recorded. During December to February 1997-1998 the El Niño event reached its mature phase with sea surface temperatures more than $2{ }^{\circ} \mathrm{C}$ above normal (i.e. above the long term mean (climatology)) in a large area of central and eastern tropical Pacific (Figure 4(a)). The associated precipitation pattern over most Amazon was of precipitation anomalies of 100 to $200 \mathrm{~mm}$ below normal (Figure 5(a) and (b)), illustrating the extent of drought conditions (precipitation deficit) in the region during the traditionally wet summer monsoon season. In March to May 1998 the decaying phase of El Niño was observed, with sea surface temperature reducing to 1 to $2{ }^{\circ} \mathrm{C}$ above normal in a large area of the central tropical Pacific (Figure 4(b)). In the tropical North
Atlantic, sea surface temperatures of 0.5 to $1{ }^{\circ} \mathrm{C}$ above normal were observed (Figure 4(b)).

According to the teleconnection analysis presented in Figure 3, abnormally warm sea surface conditions in tropical North Atlantic are associated with reduced river levels in Manaus, which are in turn related to precipitation deficit. In consistency with this analysis the associated precipitation pattern over the Amazon was of precipitation anomalies of 100 to $300 \mathrm{~mm}$ below normal, particularly in March and April 1998 near the end of the wet monsoon season (Figure 5(c) and (d)), reinforcing the drought conditions established in previous months. In May 1998, during the transition period from the end of the wet monsoon season and the start of the dry monsoon season, most of the Amazon region experienced precipitation anomalies of 50 to $100 \mathrm{~mm}$ below normal, except the northern region where precipitation anomalies remained 100 to $300 \mathrm{~mm}$ below normal (Figure 5(e)). During June to August 1998 a rapid transition to La Niña conditions was noted, with sea surface temperatures between 0.5 and $2{ }^{\circ} \mathrm{C}$ below normal observed in the central equatorial Pacific (Figure 4(c)). The associated precipitation patterns in June and July 1998 (Figure 5(f) and (g)) was of precipitation anomalies of $100 \mathrm{~mm}$ above normal in the northwest Amazon and precipitation anomalies of 25 to $50 \mathrm{~mm}$ below normal in the southwest Amazon. In August 1998 most of the Amazon region experienced precipitation anomalies of $50 \mathrm{~mm}$ below normal (Figure 5(h)). These precipitation deficits during the traditionally dry winter monsoon season reinforced drought conditions initiated earlier during the wet summer monsoon 

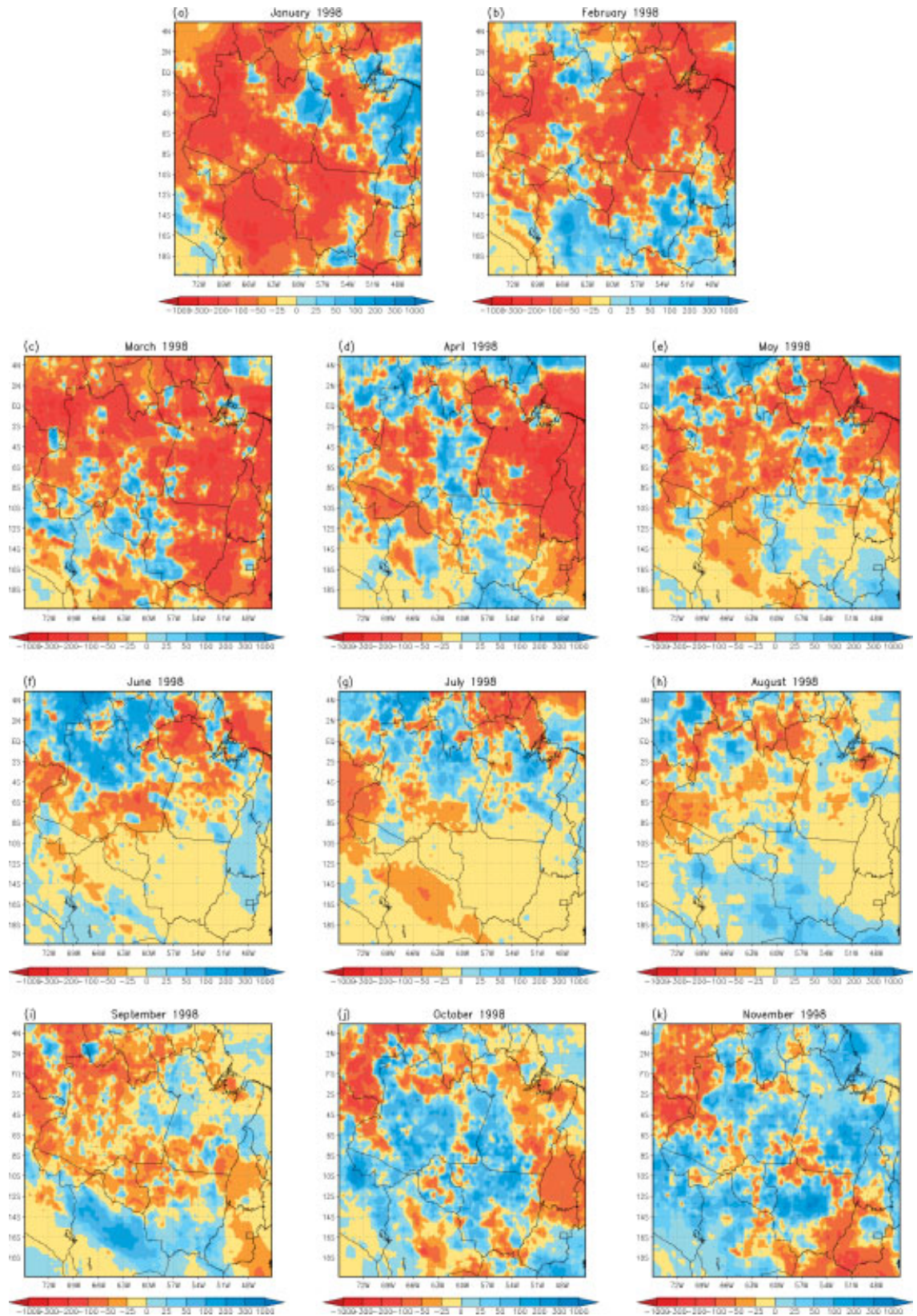

Figure 5. Observed precipitation anomalies from January (panel a) to November (panel k) 1998 from high resolution Tropical Rainfall Measuring Mission (TRMM) analysis (Huffman et al., 2007). Anomalies are computed with respect to the 1998-2010 long term mean, excluding the month for which anomaly is computed.

season. In September to November 1998 La Niña conditions strengthened, with sea surface temperatures between 1 and $2{ }^{\circ} \mathrm{C}$ below normal observed in a large area of the central equatorial Pacific (Figure 4(d)). The associated precipitation pattern in September 1998 was of anomalies of $50 \mathrm{~mm}$ below normal in most Amazon (Figure 5(i)), marking the end of drought conditions in 1998, and the start of the wet monsoon season with above normal precipitation of $100 \mathrm{~mm}$ in October and November 1998 (Figure 5(j) and (k)).

Figure 6 shows the observed sea surface temperature anomalies during December to February 2004-2005 (Figure 6(a)), March to May 2005 (Figure 6(b)), June to August 2005 (Figure 6(c)) and September to November 2005 (Figure 6(d)). During December to February 2004-2005 sea surface temperatures in the equatorial Pacific reflected the decaying phase of an El Niño event with sea surface temperatures between 0.5 and
$2{ }^{\circ} \mathrm{C}$ above normal in a confined area in western tropical Pacific (Figure 6(a)). The tropical North Atlantic presented sea surface temperatures between 0.5 and $1{ }^{\circ} \mathrm{C}$ above normal. The associated precipitation pattern over the Amazon in December 2004 (Figure 7(a)) and January 2005 (Figure 7(b)) was of precipitation anomalies of 100 to $200 \mathrm{~mm}$ below normal (Figure 7(a) and (b)), conferring drought conditions in the region during the traditionally wet summer monsoon period as a response of El Niño conditions in the Pacific and warmer than normal conditions in the tropical North Atlantic in accordance with the results from the teleconnection analysis of Figure 3.

In February 2005 (Figure 7(c)) the drought pattern started to be replaced by a pattern of above normal precipitation in several Amazonian regions, suggesting the establishment of wet conditions towards the end of the summer monsoon period. During March to May 2005 neutral conditions were observed in 
(a) Sea surface temperature anomaly DJF 2004/2005

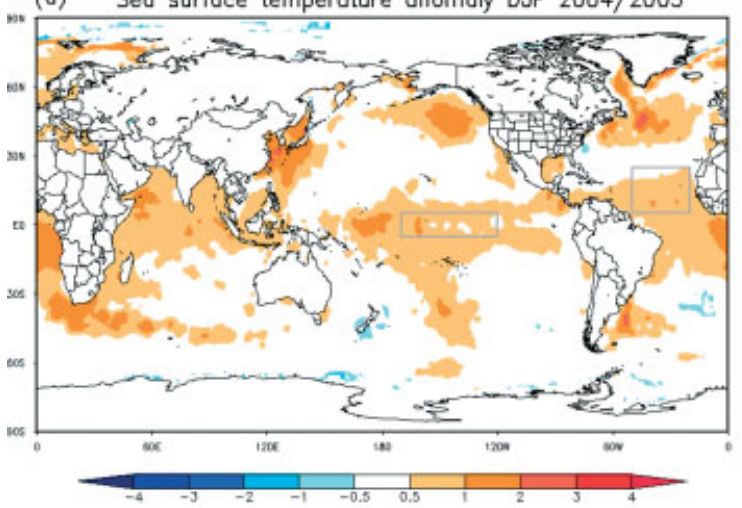

(c) Sea surface temperature anomoly JJA 1998

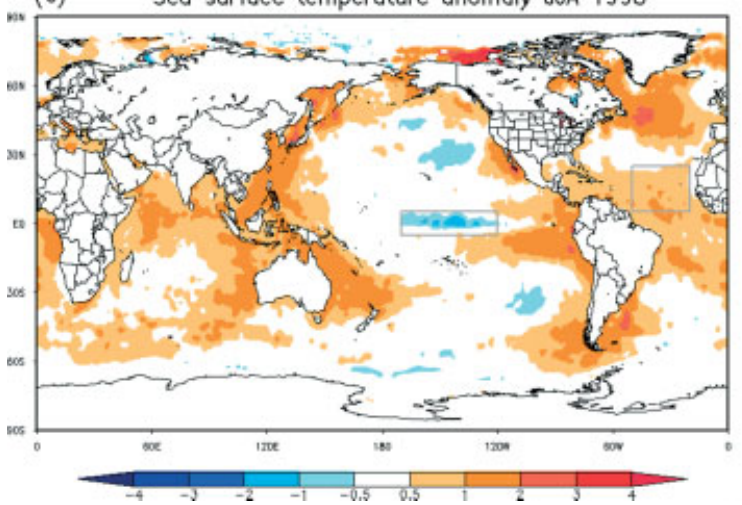

(b) Sea surfoce temperature anomay MAM 2005

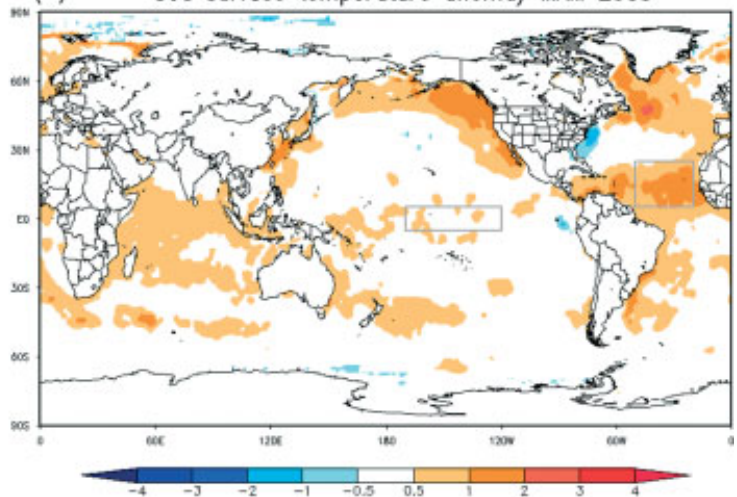

(d) Sea surfoce temperature anomaly SON 2005

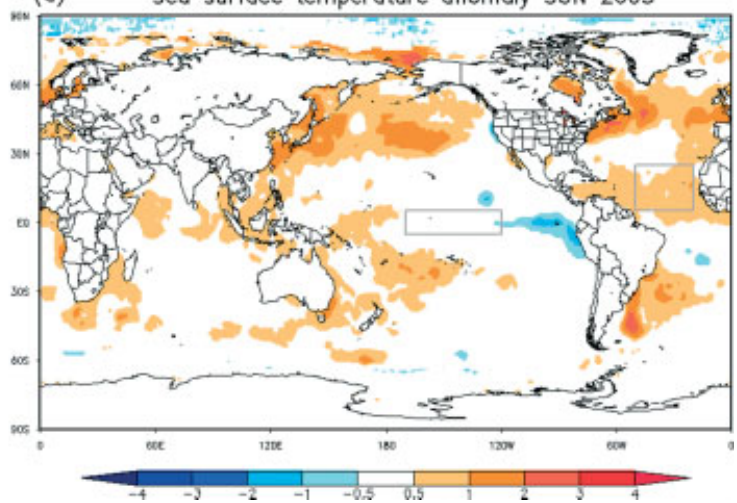

Figure 6. Observed sea surface temperature (Rayner et al., 2003) anomalies during (a) December to February 2004-2005, (b) March to May 2005, (c) June to August 2005 and (d) September to November 2005. Anomalies are computed with respect to the 1903-1996 long term mean (climatology). The boxes shown in each panel delimitate the Niño-3.4 region $\left(5^{\circ} \mathrm{N}\right.$ to $\left.5^{\circ} \mathrm{S}, 120-170^{\circ} \mathrm{W}\right)$ in the Pacific and the tropical north Atlantic region $\left(5-25^{\circ} \mathrm{N}, 20-70^{\circ} \mathrm{W}\right)$.

the equatorial Pacific, and the tropical North Atlantic warmed, with above normal sea surface temperatures of the order of 0.5 to $2{ }^{\circ} \mathrm{C}$ developing in this region (Figure 6(b)). Precipitation over the Amazon was well above normal in March 2005 (Figure 7(d)), but returned to below normal conditions of the order of 100 to $200 \mathrm{~mm}$ in April (Figure 7(e)) and of the order of 50 to $100 \mathrm{~mm}$ in May (Figure 7(f)) over the western Amazon. This evolution shows the return of prevailing precipitation deficit conditions during the transition period from the end of wet monsoon season to the start of the dry monsoon season. In June to August 2005 neutral conditions prevailed in the equatorial Pacific and warmer than normal conditions, between 0.5 to $2{ }^{\circ} \mathrm{C}$ above normal, persisted in the tropical North Atlantic (Figure 6(c)). The associated precipitation pattern was of precipitation deficits of 50 to $200 \mathrm{~mm}$ below normal in the north and northwest Amazon in June (Figure $7(\mathrm{~g})$ ) and July (Figure 7(h)) and of 25 to $50 \mathrm{~mm}$ in August (Figure 7(i)) during the dry monsoon period. This pattern of reduced precipitation has been attributed to warmer than normal conditions in tropical North Atlantic (Marengo et al., 2008) and is consistent with the results of the teleconnection analysis presented in Figure 3.

Figure 8 shows the observed sea surface temperature anomalies during December to February 2009-2010 (Figure 8(a)), March to May 2010 (Figure 8(b)), June to August 2010 (Figure 8(c)) and September to November 2010 (Figure 8(d)). During December to February 2009-2010 sea surface temperatures in the equatorial Pacific reflected the mature phase of an El Niño event with sea surface temperatures between 1 and $3{ }^{\circ} \mathrm{C}$ above normal in central and eastern tropical Pacific (Figure 8(a)). The tropical North Atlantic presented above normal sea surface temperatures of 0.5 to $2{ }^{\circ} \mathrm{C}$ above normal. The associated precipitation pattern in December 2009 (Figure 9(a)) and January 2010 (Figure 9(b)) during the traditionally wet austral summer monsoon period was of anomalies of 100 to $200 \mathrm{~mm}$ below normal in northern Amazon and of 100 to $200 \mathrm{~mm}$ above normal in southern Amazon. In February 2010 (Figure 9(c)) a considerable precipitation reduction was observed in the southern Amazon compared to the previous months. The March to May 2010 season (Figure 8(b)) was characterized by the decaying phase of El Niño in the Pacific and the area expansion and amplification in magnitude of sea surface temperatures to 1 to $2{ }^{\circ} \mathrm{C}$ above normal in the tropical North Atlantic. This ocean configuration helped establish a drought pattern in March 2010 (Figure 9(d)) with anomalies of 200 and $300 \mathrm{~mm}$ below normal over the northeast Amazon, and is in agreement with the teleconnection analysis of Figure 3. In April 2010 (Figure 9(e)) precipitation anomalies of 100 to $200 \mathrm{~mm}$ below normal were observed in the southern Amazon, while the northern Amazon experienced anomalies of 100 to $200 \mathrm{~mm}$ above normal. In May 2010 (Figure 9(f)) below normal precipitation of 100 to $200 \mathrm{~mm}$ returned to the northern Amazon, reinforcing the pattern of drought conditions in the region. This evolution shows that the prevailing precipitation deficit conditions previously observed during the wet monsoon period were reinforced during the transition period from the end of wet monsoon season to the start of the dry monsoon season. During June to August 2010 La Niña conditions 

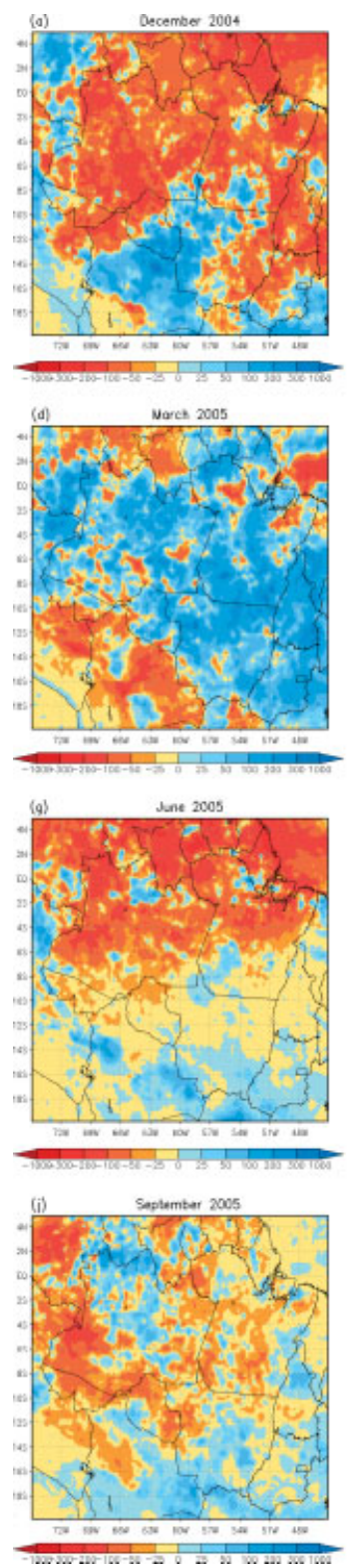
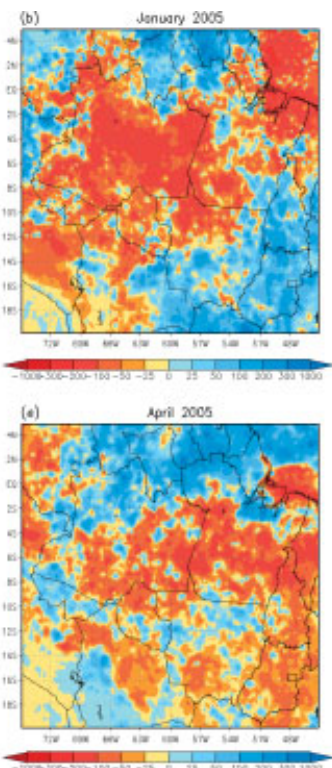

Jath 2005

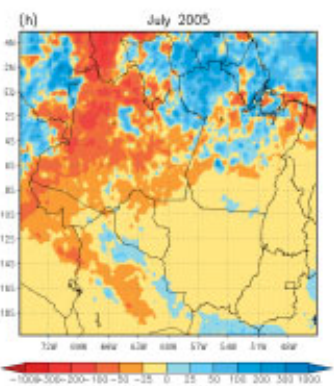

Oetatar 2005

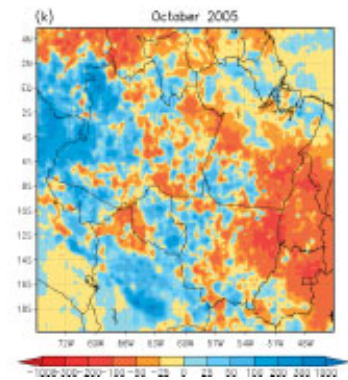

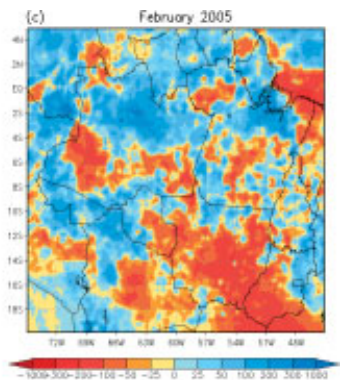

Lay 2005
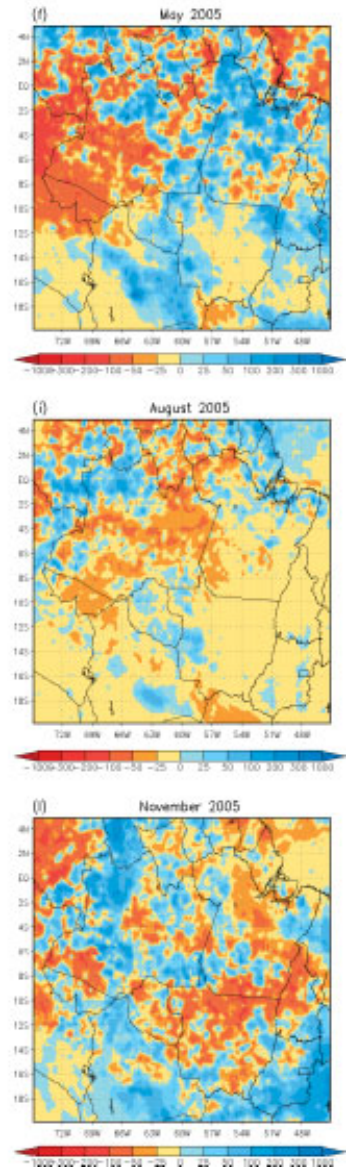

Figure 7. Observed precipitation anomalies from December 2004 (panel a) to November 2005 (panel 1) from high resolution Tropical Rainfall Measuring Mission (TRMM) analysis (Huffman et al., 2007). Anomalies are computed with respect to the 1998-2010 long term mean, excluding the month for which the anomaly is computed.

with sea surface temperature anomalies of 1 to $2{ }^{\circ} \mathrm{C}$ below normal were observed in the central Pacific (Figure 8(c)), and the tropical North Atlantic remained 0.5 to $2{ }^{\circ} \mathrm{C}$ warmer than normal. However, the area with sea surface temperature anomalies between 1 and $2{ }^{\circ} \mathrm{C}$ above normal slightly reduced compared to March to May 2010 (Figure 8(b)). The persistence of warmer than normal sea surface temperature conditions in the tropical North Atlantic prevailed over La Niña conditions in the Pacific and contributed to the maintenance of drought conditions in the northern Amazon in June 2010 (Figure 9(g)) and in the western Amazon in July (Figure 9(h)) and August (Figure 9(i)) during the dry monsoon season. In September to November 2010 the La Niña event was near its mature phase with sea surface temperature anomalies of 1 to $2{ }^{\circ} \mathrm{C}$ below normal in most of the tropical Pacific (Figure $8(\mathrm{~d})$ ). The tropical North Atlantic still presented warmer than normal sea surface temperature conditions, but now reduced to 0.5 to $1{ }^{\circ} \mathrm{C}$ above normal. The associated precipitation pattern reflected drought conditions, particularly in September (Figure 9(j)) and October (Figure $9(\mathrm{k})$ ) in the western Amazon, where deficits of 100 to $200 \mathrm{~mm}$ were observed. In November (Figure 9(1)) after several months experiencing below normal precipitation a pattern of above normal precipitation was observed in the northwestern Amazon in association with La Niña conditions in the Pacific, marking the end of drought conditions in 2010 and the beginning of the wet monsoon period in the region. As discussed further below, a common feature of two out of the three events presented here was the fact that these two events (1997-1998 and 2009-2010) presented a transition from warm to cold sea surface temperatures in the equatorial Pacific towards the end of the event, suggesting that the return to normal (precipitation) conditions in the Amazon tends to occur in unison with major changes in the Equatorial Pacific thermocline. Another important feature to be noted is the fact that the three investigated events are contrasting in their development. 

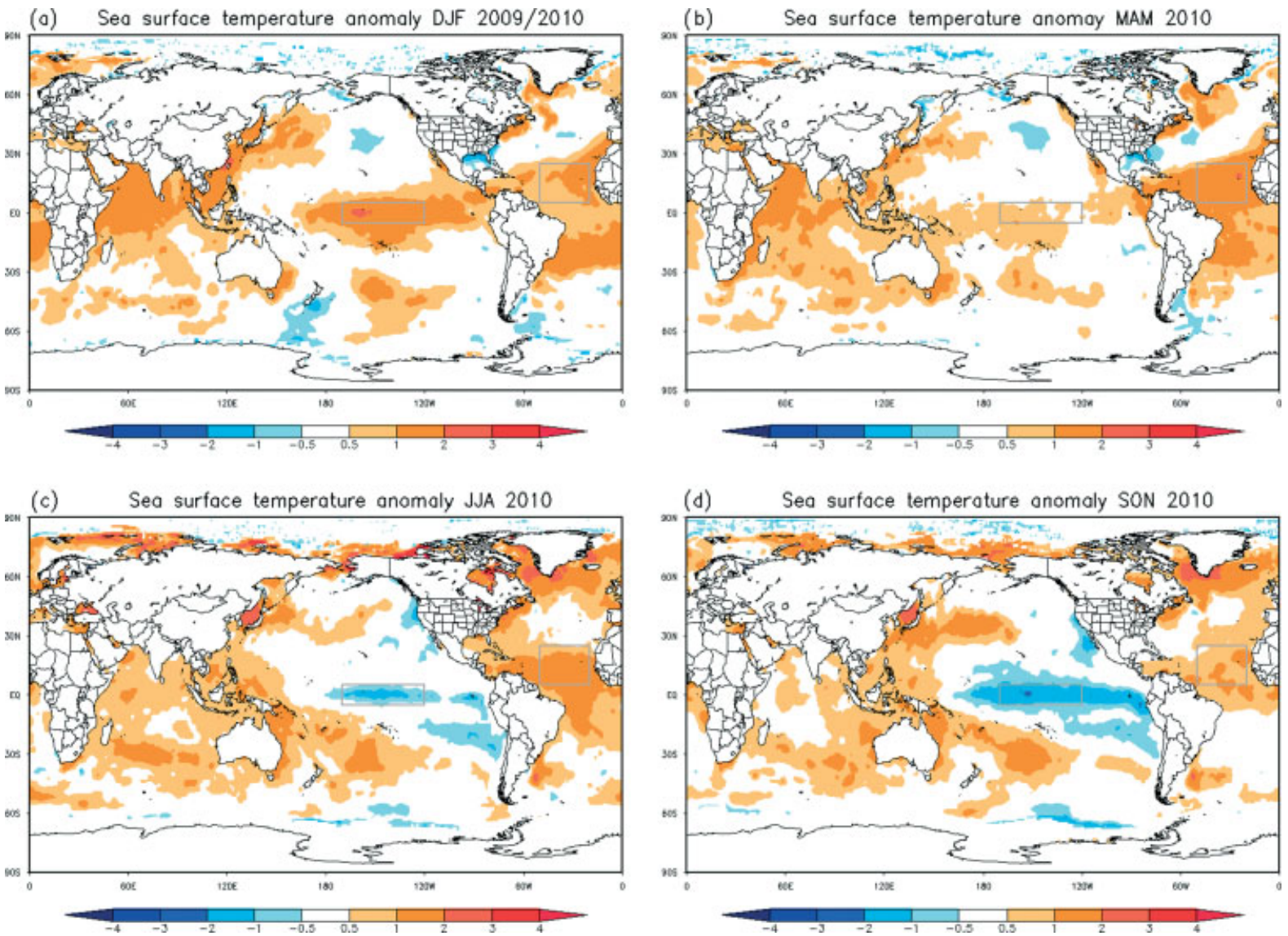

Figure 8. Observed sea surface temperature (Rayner et al., 2003) anomalies during (a) December to February 2009-2010, (b) March to May 2010, (c) June to August 2010 and (d) September to November 2010. Anomalies are computed with respect to the 1903-1996 long term mean (climatology). The boxes shown in each panel delimitate the Niño-3.4 region $\left(5^{\circ} \mathrm{N}\right.$ to $\left.5^{\circ} \mathrm{S}, 120-170^{\circ} \mathrm{W}\right)$ in the Pacific and the tropical north Atlantic region $\left(5-25^{\circ} \mathrm{N}, 20-70^{\circ} \mathrm{W}\right)$.

Figure 10(a) shows the observed sea surface temperature monthly time evolution of Niño 3.4 index (average over $5^{\circ} \mathrm{N}$ to $5^{\circ} \mathrm{S}, 120-170^{\circ} \mathrm{W}$ ) for the $1997-1998$ (solid thin line), 2004-2005 (dotted line) and 2009-2010 (dashed line) drought events. The 1903-1996 climatology is shown with the solid thick line. The 1997-1998 event (solid thin line) was marked by abnormally warm conditions in the Niño 3.4 region with sea surface temperatures more than $2{ }^{\circ} \mathrm{C}$ above climatology by November 1997 in association with the manifestation of a strong El Niño episode in the equatorial Pacific. By June 1998, a rapid transition to colder than normal conditions was observed, followed by the establishment of La Niña conditions for the remaining months of 1998. The 2009-2010 event (dashed line) shows similarities to the 1997-1998 event (solid thin line). El Niño conditions prevailed until April 2009 with peak sea surface temperature anomalies of more than $1{ }^{\circ} \mathrm{C}$ above climatology by December 2009. Although this El Niño was much weaker than the 1997-1998 event, it was followed by a rapid transition to colder than normal conditions by June 2010 and the establishment of La Niña conditions for the remaining months of 2010. The 2004-2005 event (dotted line) was marked by close to climatological conditions of the Niño 3.4 index, with slightly warmer than normal conditions until July 2005, very close to normal conditions until November 2005 and slightly colder than normal conditions in December 2005.

Figure 10(b) shows the observed north tropical Atlantic (average over $5-25^{\circ} \mathrm{N}, 20-70^{\circ} \mathrm{W}$ ) sea surface temperature monthly time evolution for the 1997-1998 (solid thin line), 2004-2005 (dotted line) and 2009-2010 (dashed line) drought events. The 1903-1996 climatology is shown with the solid thick line. In all three events abnormally warmer than normal conditions prevailed in the tropical North Atlantic, with larger departures from climatology observed in the second year of the event (i.e. after December 1997, 2004 and 2009). The 2009-2010 event (dashed line) shows the largest departures from climatology (of the order of $1{ }^{\circ} \mathrm{C}$ in March 2010) compared to the 1997-1998 and 2004-2005 events. The warming pattern of the 2004-2005 event (dotted line) shows similarities to the 2009-2010 event (dashed line), particularly from June to December 2005 and 2009. Sea surface temperatures in the tropical North Atlantic during the 1997-1998 event (solid thin line) were generally cooler than for the 2009-2010 and 2004-2005 events. Figure 10(c) shows the time series of annual mean tropical North Atlantic (average over $5-25^{\circ} \mathrm{N}$, $20-70^{\circ} \mathrm{W}$ ) sea surface temperature. The central horizontal solid line is the long-term (1870-2010) annual mean climatology of $26.16 \mathrm{C}$. The other two solid horizontal lines represent the upper and lower terciles of 26.31 and $26.01{ }^{\circ} \mathrm{C}$, respectively. The annual mean temperatures for 1998, 2005 and 2010 appear as the three largest values on record, all located in the upper tercile of the distribution. The dashed horizontal line puts the record value of $27.20^{\circ} \mathrm{C}$ measured in 2010 in climate perspective (i.e. the largest value on record), representing an anomaly of $1.04{ }^{\circ} \mathrm{C}$ with respect to the $1870-2010$ long-term mean. 

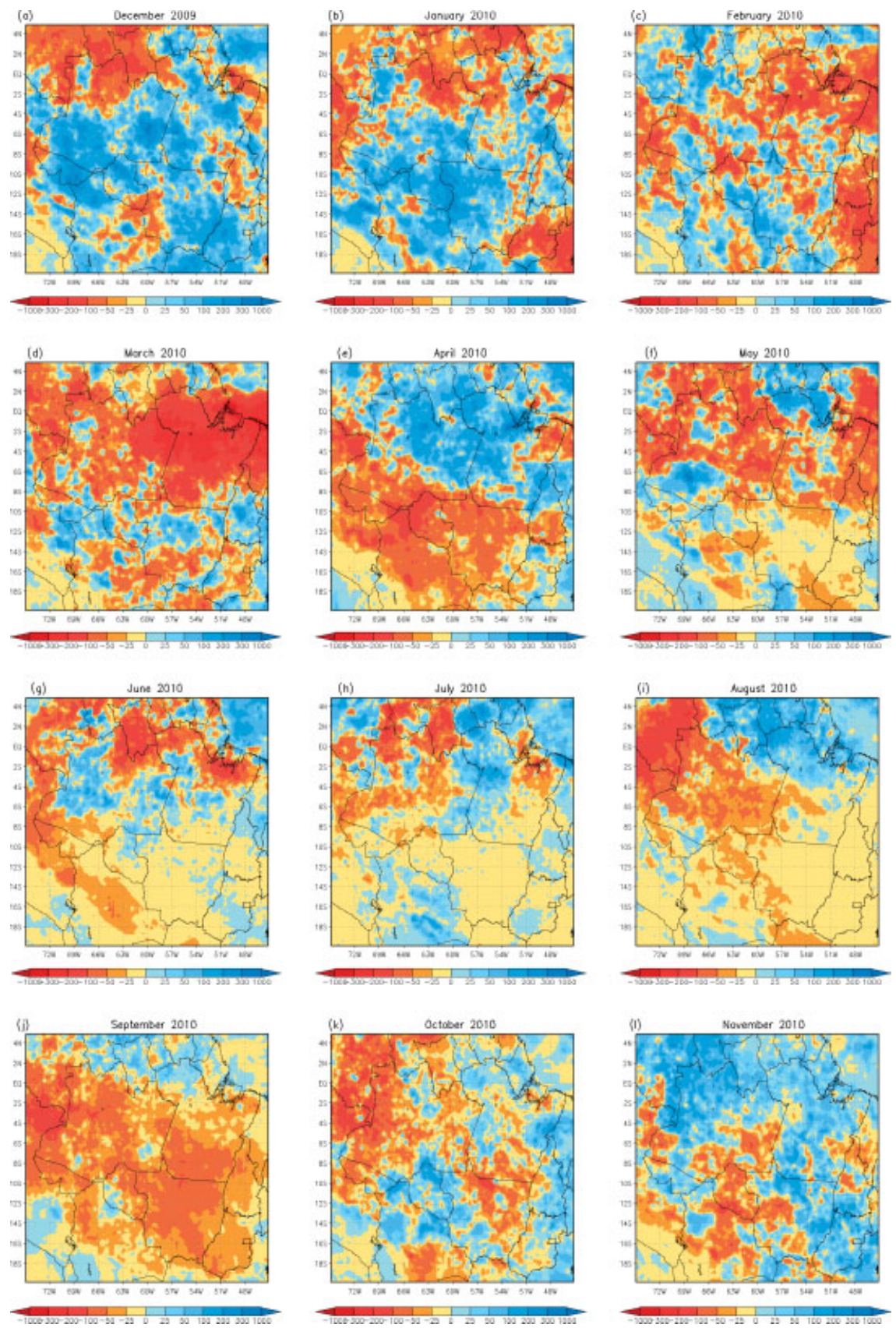

Figure 9. Observed precipitation anomalies from December 2009 (panel a) to November 2010 (panel l) from high resolution Tropical Rainfall Measuring Mission (TRMM) analysis (Huffman et al., 2007). Anomalies are computed with respect to the 1998-2010 long term mean, excluding the month for which anomaly is computed.

Figure 11 shows the observed annual precipitation anomalies for 1998, 2005 and 2010. Anomalies are computed with respect to January to December calendar year (Figure 11(a)-(c)) and also with respect to the precipitation annual cycle starting in November of the previous year to October of the current year, i.e. November 2004 to October 2005 for the 2004-2005 event (Figure 11(e)) and for November 2009 to October 2010 for the 2009-2010 event (Figure 11(f)). For the 2008 event, anomalies for the precipitation cycle have been computed for the period January to October 1998 due to the fact that TRMM precipitation data are only available from January 2008 (Figure 11(d)). The computation of annual anomalies for the calendar year is prone to combining precipitation from one precipitation cycle to the next. Therefore, by considering the precipitation annual cycle starting in November and ending in October this combination is avoided. The comparison of annual anomalies of Figure 11(a)-(c) with the anomalies of Figure 11(d)-(f) is useful for checking the consistence and robustness of the identified precipitation anomaly patterns for the three investigated drought events. In 1998 (Figure 11(a) and (c)), a very large area of the Amazon experienced deficits above $400 \mathrm{~mm}$, illustrating a pattern of generalized drought conditions. In 2005 (Figure 11(b)), precipitation anomalies of the same order of magnitude were restricted to the southwestern Amazon, and a widespread drought pattern extending to eastern Amazon appears when the November 2004 to October 2005 cycle is considered (Figure 11(e)). In 2010 (Figure 11(c)), drought conditions were noticed in almost all the 

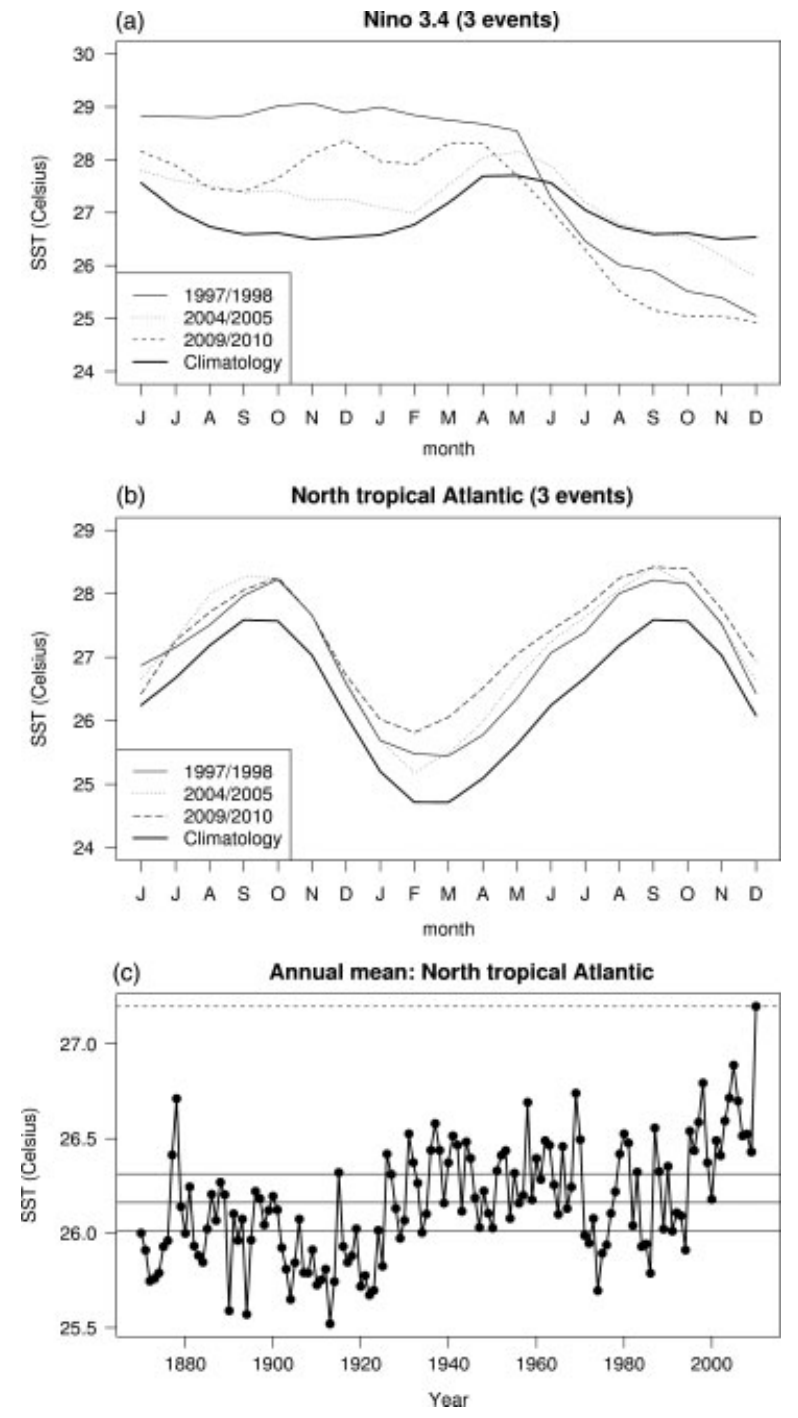

Figure 10. Observed monthly evolution of (a) Niño 3.4 index (average over $5^{\circ} \mathrm{N}$ to $5^{\circ} \mathrm{S}, 120-170^{\circ} \mathrm{W}$ ) and (b) tropical north Atlantic (average over $5-25^{\circ} \mathrm{N}, 20-70^{\circ} \mathrm{W}$ ) sea surface temperatures (Rayner et al., 2003) for the 1997-1998 (solid thin line), 2004-2005 (dotted line) and 2009-2010 (dashed line). The 1903-1996 climatology is shown with a solid thick line. (c) Time series of annual mean north tropical Atlantic sea surface temperature. The central horizontal solid line is the long-term (1870-2010) annual mean climatology of $26.16^{\circ} \mathrm{C}$. The other two solid horizontal lines represent the upper and lower terciles of 26.31 and $26.01{ }^{\circ} \mathrm{C}$, respectively. The dashed horizontal line is the value of $27.20^{\circ} \mathrm{C}$ measured in 2010 .

Amazon region, however the area with deficits above $400 \mathrm{~mm}$ was much reduced compared to 1998 (Figure 11(a)), and when the November 2004 to October 2005 cycle is considered (Figure 11(e)) the intensity of the deficits in northern Amazon becomes similar to 1998 (Figure 11(a) and (d)). Figure 11 illustrates that the spatial extent of the 1998 drought event was much larger than during the 2005 and 2010 event, suggesting that precipitation deficits in the monsoon-like regime were more widespread in 1998 when compared to 2005 and 2010.

\section{Large-scale circulation patterns}

This section presents an analysis of large scale circulation patterns observed during the July to September dry monsoon seasons of 1998, 2005 and 2010, representing the most relevant period when drought conditions usually impact river levels in the Amazon later in the period October to December. As identified earlier in Section 3 this is an important period when marked teleconnections with the tropical North Atlantic operate (Figure 3). Figure 12(a)-(c) show vertical velocity (omega) in the mid troposphere (500 hPa) for July to September 1998, 2005 and 2010, respectively. These figures illustrate the predominance of upward vertical motion (negative values in blue) in the tropical North Atlantic, where above normal sea surface temperatures were observed (Figure 10(b)). This zonal pattern of vertical motion in the north tropical Atlantic highlights the region where the Inter-Tropical Convergence Zone (ITCZ) acts. Upward vertical motion is also observed in northern South America, where positive precipitation anomalies were observed (Figures 5(g), 7(h)-(j), 9(h)-(j)). To the south of this region, particularly in 1998 (Figure 12(a)) and 2010 (Figure 12(c)), along $10^{\circ} \mathrm{S}$ over central Brazil, downward vertical motion (positive values in orange) prevailed, characterizing a subsidence pattern inhibiting cloud formation and precipitation. In consistency with this pattern, below normal precipitation was observed in the south Amazon (Figures 5(g)-(i), 7(h)-(j), 9(h)-(j)) reinforcing precipitation deficits during the dry monsoon season. This meridional circulation pattern with upward motion over the tropics and descending motion over South America defines the local Hadley Cell. Figure 12(d)-(f) illustrate these Hadley Cells for July to September 1998, 2005 and 2010 by showing the meridional cross-section of vertical velocity anomalies given by the mean values over the Amazon region between 73 and $58^{\circ} \mathrm{W}$ from 1000 to $100 \mathrm{hPa}$. Particularly for 1998 (Figure 12(d)) and 2010 (Figure 12(f)), the Hadley Cell is identified by upward vertical motion (negative values of vertical velocity anomalies in blue) in the region around and to the north of the equator, and downward vertical motion (positive values of vertical velocity anomalies in orange) around $10^{\circ} \mathrm{S}$. Over the central Amazon close to null vertical velocity anomalies were observed (Figure 12(d)-(f)), representing a transition region between upward motion to the north and downward motion to the south.

Figure 13(a)-(c) shows velocity potential anomalies (shaded) and divergent wind component anomalies (vectors) at $200 \mathrm{hPa}$ for July to September 1998, 2005 and 2010, respectively, illustrating regions of mass convergence and divergence in the upper troposphere. Negative velocity potential anomalies (in blue) indicate regions of mass divergence in the upper troposphere associated with deep convection and cloud formation as, for example, over Indonesia and the tropical North Atlantic. This pattern in the tropical North Atlantic is consistent with above normal sea surface temperatures observed in July to September (Figure 10(b)) and upward vertical motion (Figure 12). Positive velocity potential anomalies (in orange) indicate regions of mass convergence in the upper troposphere associated to downward vertical motion (i.e. subsidence inhibiting cloud formation) as, for example, over the central equatorial Pacific, where below normal sea surface temperatures associated to La Niña prevailed in 1998 and 2010 (Figure 10(a)).

Figure 13(d)-(f) show humidity flux divergence (shaded) and wind anomalies (vectors) at $850 \mathrm{hPa}$ for July to September 1998, 2005 and 2010. Areas highlighted in orange and red (e.g. western Mato Grosso State) represent regions with humidity flux divergence at low levels of the atmosphere, and therefore are unfavourable for cloud formation. Areas in blue represent regions with humidity flux convergence, favouring cloud formation. Although in all three events most Amazon 

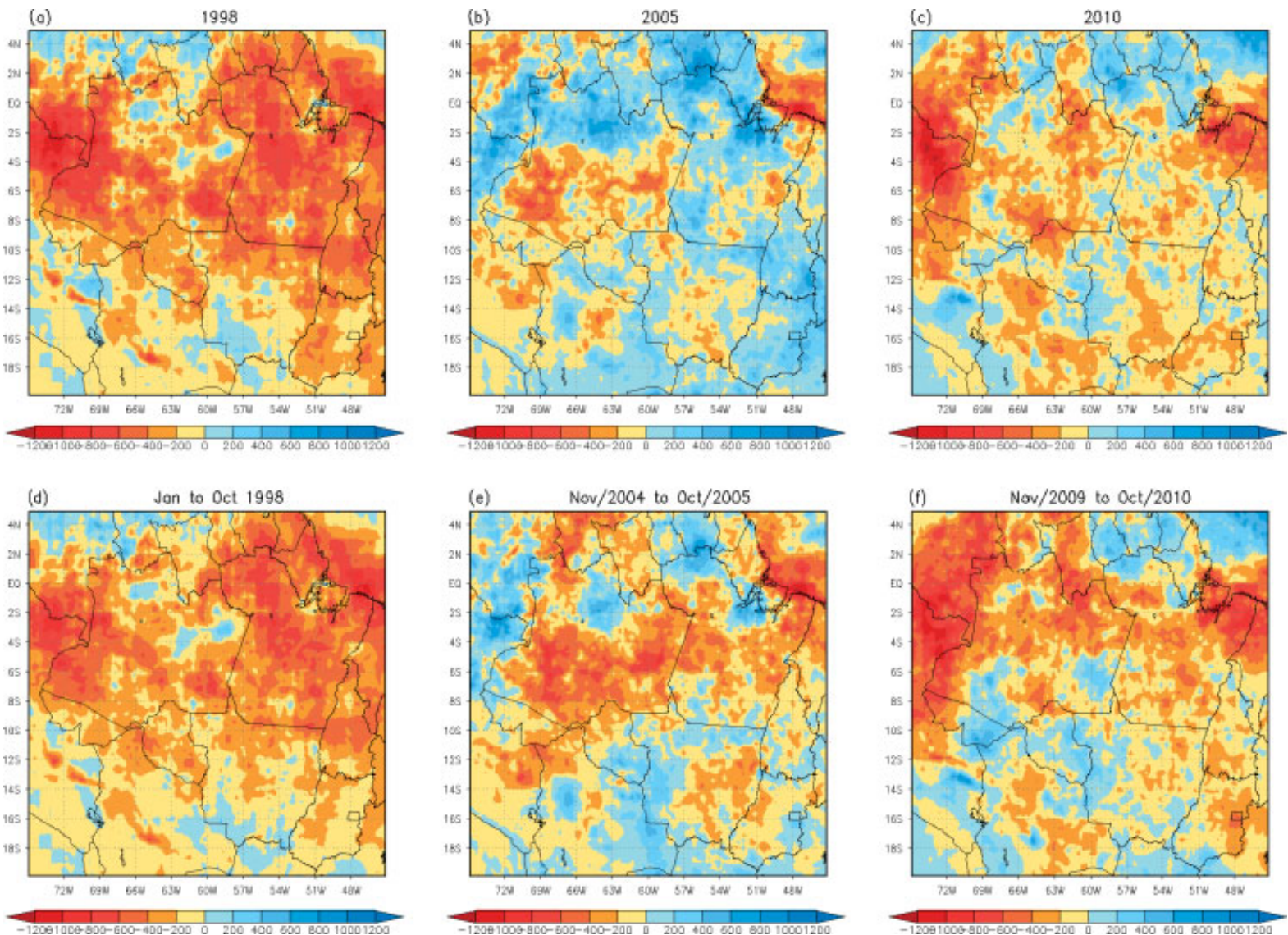

Figure 11. Observed annual (January to December calendar year) precipitation anomalies for (a) 1998, (b) 2005 and (c) 2010 from high resolution TRMM analysis (Huffman et al., 2007). Anomalies for the period from November of the previous year to October of the current year, i.e. November 2004 to October 2005 for the 2004-2005 event are shown in (e) and for November 2009 to October 2010 for the $2009-2010$ event in (f). Panel (d) shows anomalies for the period from January to October 1998 as TRMM precipitation data is only available from January 2008.

Anomalies are computed with respect to the 1998-2010 long term mean, excluding the year for which anomaly is computed.

presented a pattern of humidity flux convergence favourable for cloud formation, the region has not presented the necessary dynamical conditions with absence of upward vertical motion for effectively producing precipitating clouds. Another common feature of the three events illustrated in Figure 13(d)-(f) is the pattern of westerly low level wind anomalies (green lines) along the equator over the Amazon, turning to southwesterly anomalies towards the North Atlantic in 2005 and 2010. This anomalous circulation pattern is consistent with reduced humidity transport from the North Atlantic towards the Amazon and reduced precipitation. From another perspective, during the three drought events humidity was transported from the Amazon to the North Atlantic.

\section{The effect of aerosol on cloud formation}

The previous section described the large scale dynamical mechanisms that contributed to the observed drought conditions during the dry monsoon season over the Amazon in July to September 1998, 2005 and 2010 with direct impacts on water availability later in October, November and December of these years. The primary highlighted mechanism was the establishment of an anomalous local Hadley circulation with upward vertical motion over an abnormally warm sea surface in the north tropical Atlantic and prevailing downward vertical motion (subsidence) over the Amazon, inhibiting cloud formation and precipitation. This section aims to diagnose aerosol conditions over the Amazon and to discuss the possible effect aerosol may have in further inhibiting precipitation efficiency as an additional and secondary mechanism contributing to the observed drought patterns in 2005 and 2010. Aerosol is investigated using aerosol optical depth inferred by the Moderate Resolution Imaging Spectroradiometer (MODIS) instrument on board of Terra satellite (Remer et al., 2005). Aerosol optical depth (also known as aerosol optical thickness) is a measure of radiation extinction due to the interaction of radiation with aerosol particles in the atmosphere primarily associated with scattering and absorption processes. Aerosol optical depth is a dimensionless wavelengthdependent parameter that indicates the attenuation a radiation beam suffers as it passes through an atmospheric layer containing aerosols. It is, therefore, a proxy for aerosol concentration in the atmosphere.

Figure 14(a) shows the aerosol optical depth (at $550 \mathrm{~nm}$ ) annual cycle for the region $5-15^{\circ} \mathrm{S}, 50-70^{\circ} \mathrm{W}$, representing the core region of biomass burning emission in central South America. The solid thick line is the 2001-2010 long-term mean (climatology). From January to July aerosol optical depth oscillates around 0.1 , which is considered the background level of commonly observed atmospheric aerosol. From August to December it is clearly noticed that the aerosol optical depth increases in response to biomass burning, particularly during the dry monsoon season months (Koren et al., 2007) usually associated with fire land management for agricultural and cattle activities. In August aerosol optical depth reaches the level 

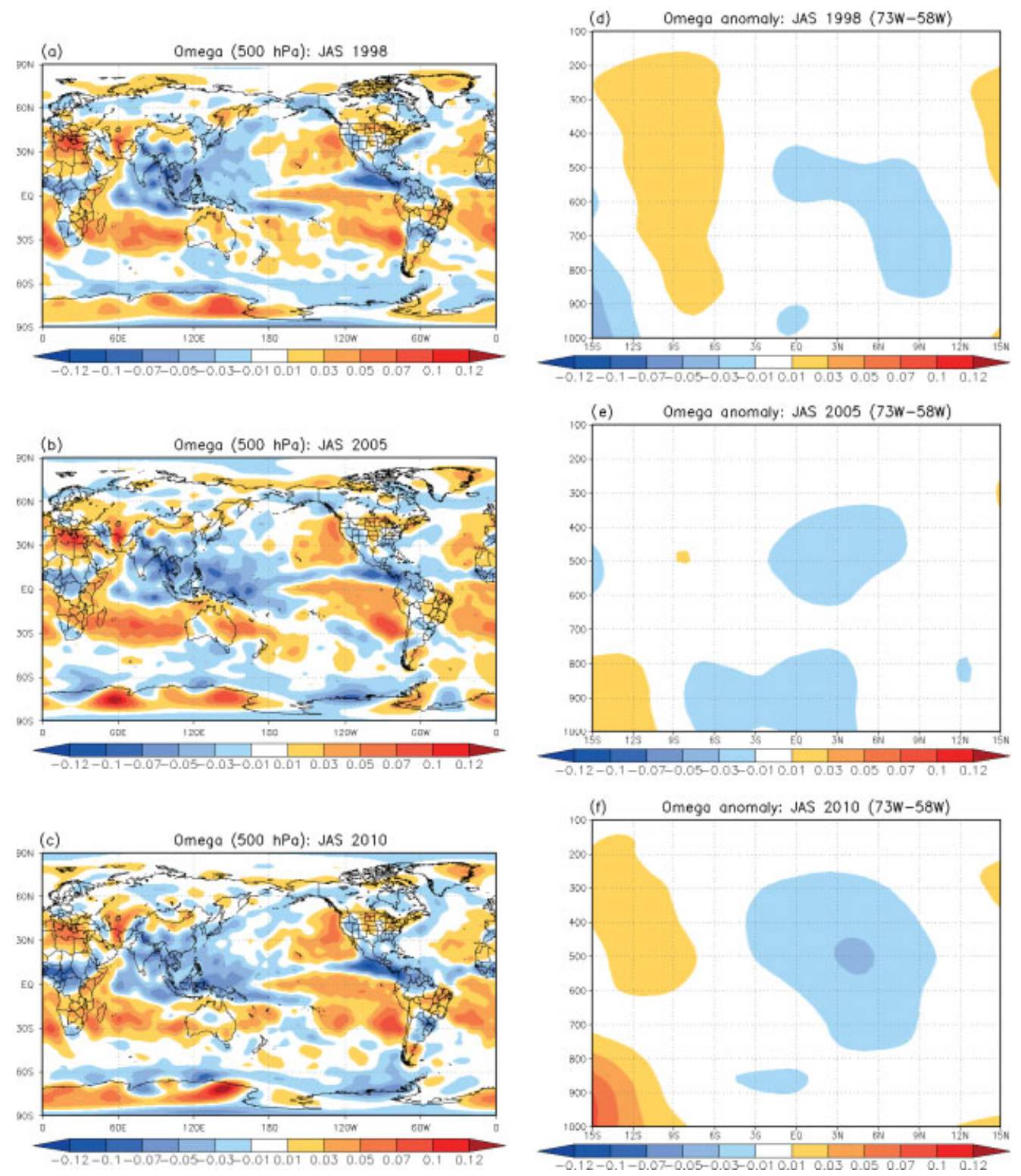

Figure 12. Seasonal mean July to September vertical velocity (omega) $\left(\mathrm{Pa} \mathrm{s}^{-1}\right.$ ) at $500 \mathrm{hPa}$ for (a) 1998, (b) 2005 and (c) 2010 (Kalnay et al., 1996; Kanamitsu et al., 2002). Meridional cross-section of vertical velocity anomalies $\left(\mathrm{Pa} \mathrm{s}^{-1}\right)$ for the longitude band $73-58^{\circ} \mathrm{W}$ from 1000 to $100 \mathrm{hPa}$ for July, August and September (d) 1998, (e) 2005 and (f) 2010. Anomalies are computed with respect to the 1948-2010 climatology.

of 0.4 and in September it peaks at the level of 0.8 . In October, with the return of precipitation at the beginning of the wet monsoon season, aerosol optical depth starts to decline, returning to a level close to the background of 0.1 in December. The solid thin line is the observed annual cycle in 2005 and the dashed line is the corresponding observed annual cycle in 2010. Both years presented similar evolution, reaching a level of 0.75 in August (a level close to the climatological level of 0.8 typically observed 1 month later in September, the peak climatological month) and 1.0 in September. These values are well above climatology, indicating the excessive human insertion of biomass burning aerosol into the atmosphere during the dry monsoon season. In October 2005 aerosol optical depth was slightly above climatology while in October 2010 is was slightly below climatology.

Figure 14(c)-(f) show aerosol optical depth anomalies for August, September and October 2005 and 2010, respectively. One can clearly notice in both years the large spatial extent of positive aerosol optical depth anomalies over central South America in August and September, indicating abnormal biomass burning activities and excessive presence of aerosol in the atmosphere during the dry monsoon season. The corresponding precipitation patterns are of prevailing negative anomalies over the Amazon (Figures 7(i) and (j); and 9(i) and $(\mathrm{j})$ ), suggesting a negative association between precipitation and presence of aerosol in the atmosphere. This negative association is illustrated in Figure 14(b) and shows a scatter plot between the mean aerosol optical depth and precipitation within the region $5-15^{\circ} \mathrm{S} 50-70^{\circ} \mathrm{W}$ for September 2001-2010. In October, with the start of the wet monsoon season, positive aerosol optical depth anomalies are restricted to confined smaller regions. The possible physical mechanisms leading to the effect of aerosol in cloud formation are summarized as follows. The expressive increase of biomass burning aerosol, which acts as cloud condensation nuclei for cloud droplet formation, can reduce the precipitation formation 
(a) Velocity Potencial Anomaly $200 \mathrm{hPa}$ - JAS 1998

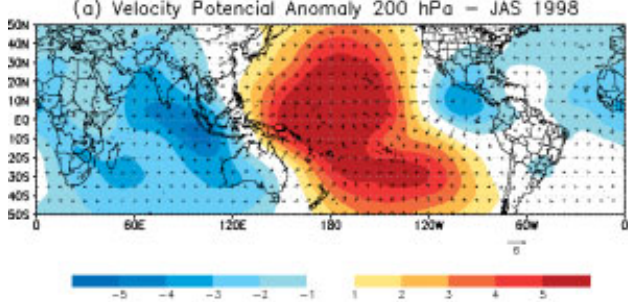

(b) Velocity Potencial Anomaly $200 \mathrm{hPa}$ - JAS 2005

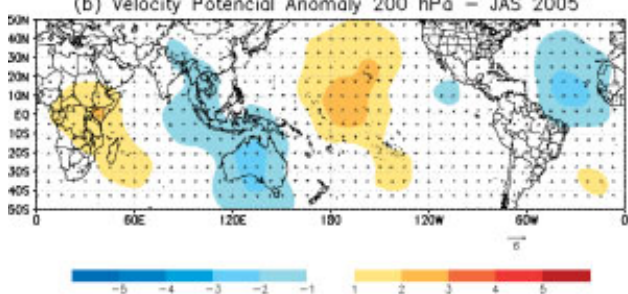

(c) Velocity Potencial Anomaly 200 hPo - JAS 2010

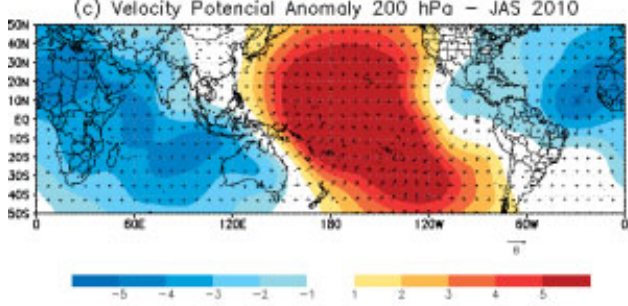

(d) Humidity flux div. and wind streamline onomaly: JAS 1998

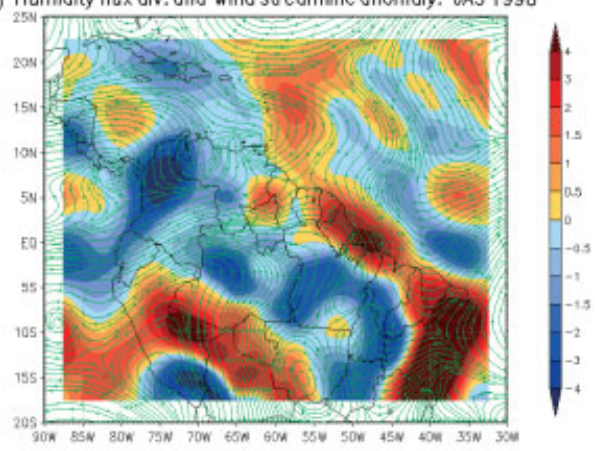

(e) Humidity flux div, and wind streamline anomaly: JAS 2005

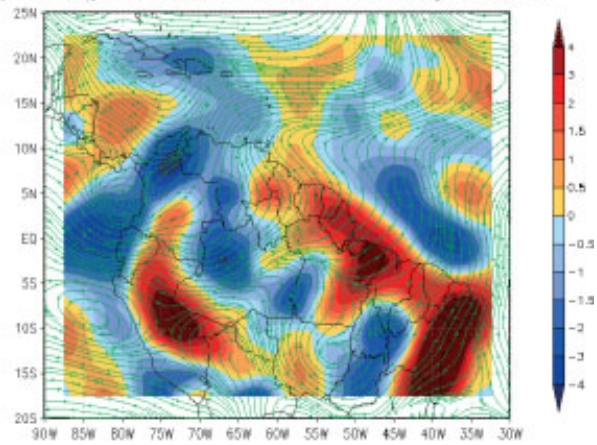

(f) Humidity flux div. and wind streamline anomaly: JAS 2010

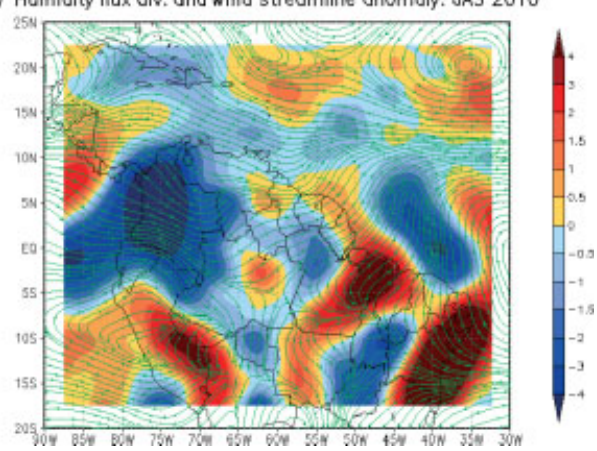

Figure 13. Seasonal mean July to September velocity potential anomalies $\left(10^{6} \mathrm{~m}^{2} \mathrm{~s}\right.$, shaded) and divergent wind anomalies (m $\mathrm{s}-1$, vectors) at $200 \mathrm{hPa}$ for (a) 1998, (b) 2005 and (c) 2010. Humidity flux divergence ( $\mathrm{g} \mathrm{Kg}^{-1} \mathrm{~s}^{-1}$, shaded) and wind streamline anomalies (green lines) at $850 \mathrm{hPa}$ for July to September (d) 1998, (e) 2005 and (f) 2010.

process efficiency (Rosenfeld, 1999; Ramanathan et al., 2001; Khain et al., 2005; Martins et al., 2009). Even for a moist saturated atmosphere, due to the abundant amount of aerosol, size droplets may not grow enough to precipitate in the form of rain (Twomey, 1974; Silva Dias et al., 2002; Koren et al., 2004). As a result of this process clouds may form with reduced droplet sizes, but precipitation in the form of rain might not occur (Miller et al., 2004). In addition to this effect, biomass burning aerosols are efficient in solar radiation absorption and scattering (Ramanathan et al., 2001; Lau et al., 2006; Ramanathan and Carmichael, 2008). The smoke that reaches the top of the atmosphere absorbs solar radiation and may heat the atmosphere at high levels (Hansen et al., 1997; Hobbs et al., 1997; Ramanathan et al., 2001; Kaufman et al., 2002; Stone et al., 2008). At the same time, the smoke can reduce the amount of solar radiation that reaches the surface of the Earth (Albrecht et al., 1989; Penner et al., 1992; Wood and Bretherton, 2006). The likely net result of this process is to increase the atmosphere thermodynamic stability (Ackerman et al., 2000; Andreae et al., 2004; Koren et al., 2004; Feingold et al., 2005; Fan et al., 2008). In a more stable atmosphere moist air mass vertical developments near the surface are inhibited, and therefore cloud formation may be reduced (Lynn et al., 2007; Fan et al., 2008).

Although the physical mechanisms discussed above are sound and well documented in the literature, one could argue that the relationship between aerosol optical depth and precipitation shown in Figure 14(b) might have resulted from late wet monsoon season onsets, long dry monsoon season duration and, consequently, increased biomass burning aerosol. As illustrated in Figures 7 and 9 dry conditions were observed during the wet monsoon season and persisted during the dry monsoon season. The amount of biomass burning aerosol depends on rainfall onset in the wet monsoon season (Zhang et al., 2009). Late wet monsoon season onsets also depend on largescale forcing (Marengo et al., 2001; Zhang et al., 2008). As previously discussed in Section 4 subsidence enhancement and circulation changes due to large-scale forcing are likely to be the primary mechanism for the persistence and intensity of drought conditions in the Amazon in 2005 and 2010. Further investigations with physically based numerical model experiments and site-specific observations are required to confirm the 
(a) Aerosol optical depth annual cycle (5S -15S, 50W -70W)
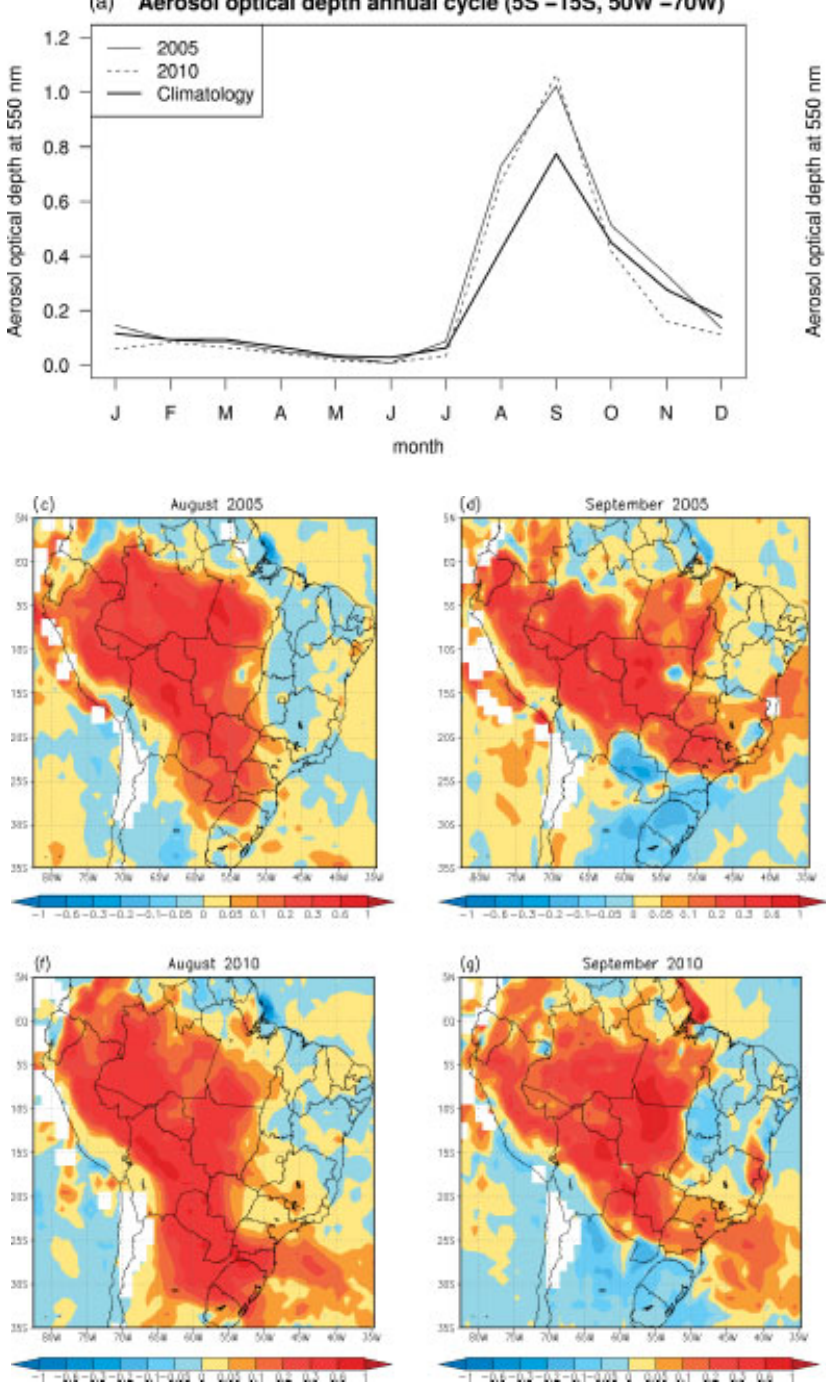

(b) Regression: AOD x Precipitation

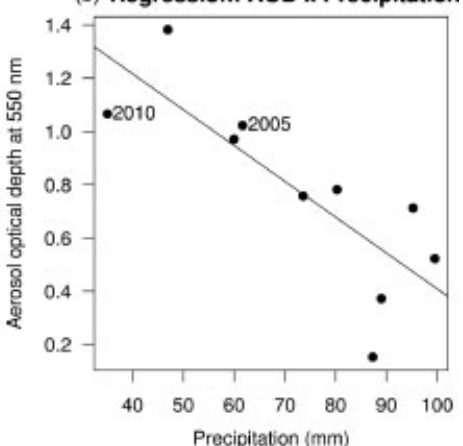

Qetober 2005
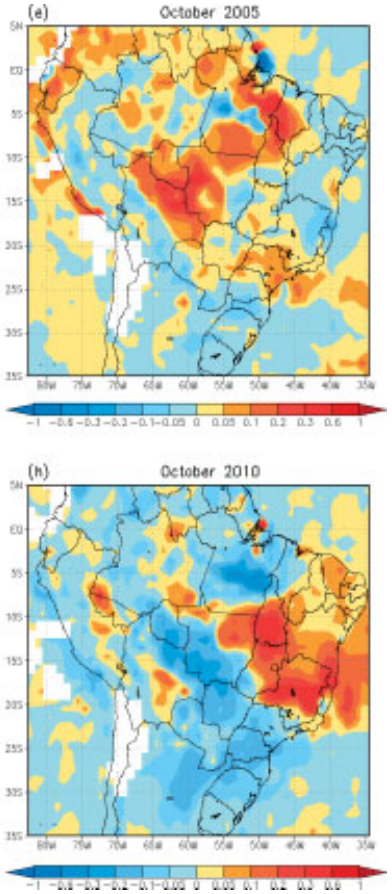

Figure 14. (a) Aerosol optical depth (at $550 \mathrm{~nm}$ ) annual cycle for the region $5-15^{\circ} \mathrm{S} 50-70^{\circ} \mathrm{W}$ inferred from MODIS instrument on board of Terra satellite. The solid thick line is the 2001-2010 long-term mean (climatology). The solid thin line is the annual cycle for 2005 and the dashed line is the annual cycle for 2010. (b) Scatter plot between the mean aerosol optical depth and TRMM precipitation within the region $5-15^{\circ} \mathrm{S} 50-70^{\circ} \mathrm{W}$ for September $2001-2010$. The black line is the regression fit to this sample $\left(R^{2^{\circ}}={ }^{\circ} 0.64\right.$, slope estimate equals to $-0.013 \mathrm{~mm}^{-1}$ ). The drought events of 2005 and 2010 are indicated in the scatter plot. Panels (c-e) show aerosol optical depth anomalies for August, September and October 2005, respectively. Panels (f-h) show aerosol optical depth anomalies for August, September and October 2010, respectively. Anomalies are computed with respect to the 2001-2010 long term mean, excluding the month for which anomaly is computed. This aerosol optical depth dataset was obtained from NASA GES DISC GIOVANNI system (Acker and Leptoukh, 2007) and is known as MODIS level-3 monthly mean gridded product at the horizontal regular resolution of $1^{\circ}$ in latitude by $1^{\circ}$ in longitude.

secondary mechanisms of biomass burning aerosol modifying cloud physics discussed here and the role of aerosol on the 2005 and 2010 droughts as diagnosed in this section in combination with the effect of large-scale forcing.

\section{Precipitation seasonal predictions for July to September 1998, 2005 and 2010}

In the same way that it is important to diagnose the observed climate conditions for understanding the mechanisms leading to drought events in the Amazon, it is also important to assess how well these events are predicted. This section presents an assessment of predicted precipitation anomalies for the dry monsoon seasons of July to September 1998, 2005 and 2010 produced in the previous June with CPTEC/AGCM (Cavalcanti et al., 2002; Marengo et al., 2003).
CPTEC is 1 of the 12 designated World Meteorological Organization (WMO) Global Producing Center for long-range forecasts (GPC, http://climal.cptec.inpe.br/gpc) Seasonal climate forecasts are operationally produced using CPTEC/AGCM with persistent sea surface temperature anomalies (Reynolds et al., 2002). For example, for a forecast made in June 2010 and valid for the season July to September 2010, the observed sea surface temperature anomaly of the previous May 2010 is added to the climatological (i.e. long term mean) sea surface temperature of each month from June to September during the integration of the model. The model resolution is T062L28, which represents triangular truncation of 62 waves in the horizontal co-ordinate and 28 levels in the vertical sigma co-ordinate ( 21 in the troposphere and 7 in the stratosphere). Deep cloud convection is parameterized using the scheme developed by Kuo (1974). Initial conditions for these operational forecasts are obtained from NCEP/NCAR reanalysis (Kalnay et al., 1996; Kanamitsu 

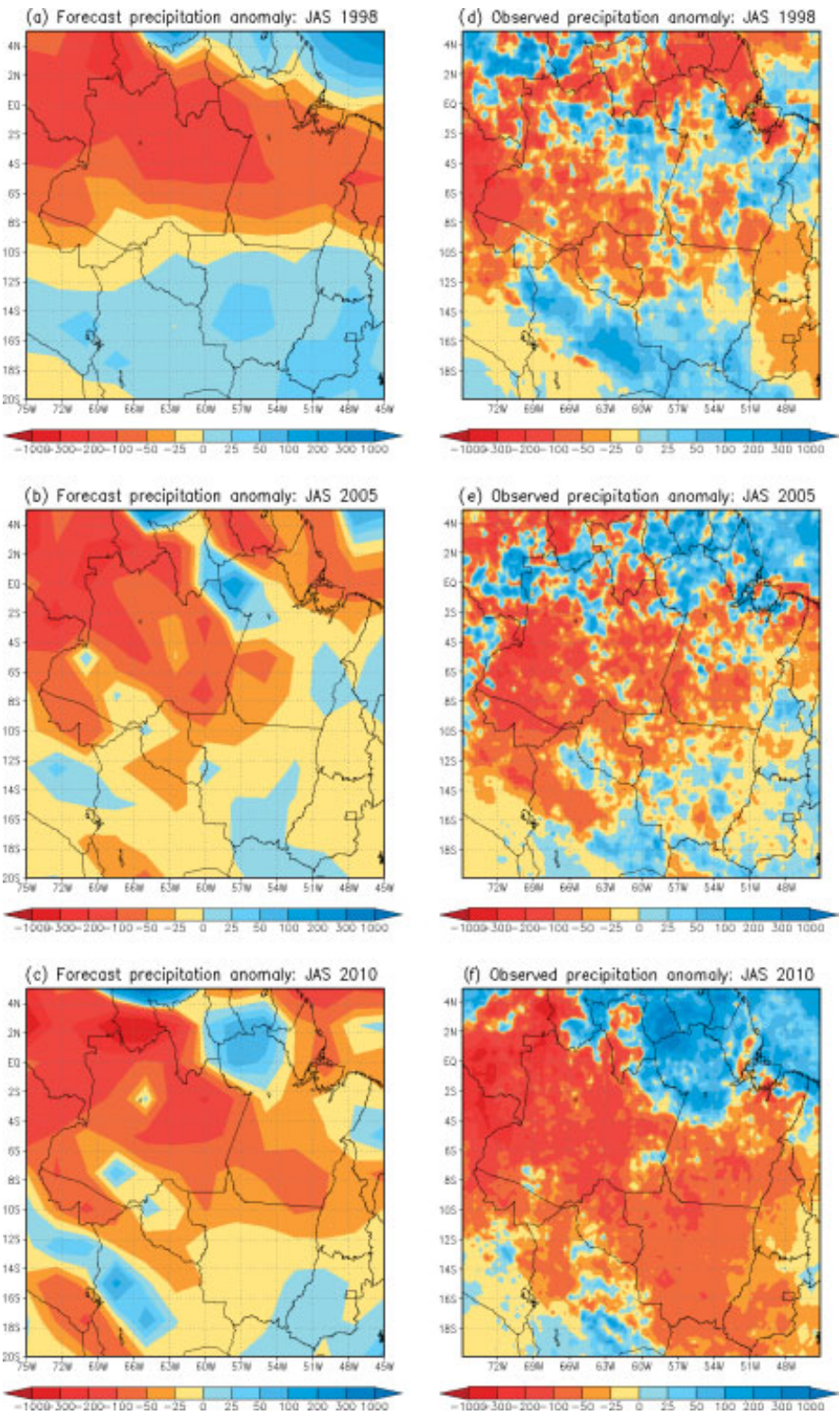

Figure 15. Forecast precipitation anomalies (mm) for July, August, September (a) 1998, (c) 2005 and (e) 2010 produced in the previous June with CPTEC/AGCM. Observed precipitation anomalies (mm) for July, August, September (b) 1998, (d) 2005 and (f) 2010 from TRMM analysis (Huffman et al., 2007).

et al., 2002). A total of 15 initial conditions from the previous March in the example above, representing 15 different days of March 2010, are used for producing an ensemble of forecasts. The operational procedure therefore uses a lagged initialization approach.

Figure 15(a)-(c) show CPTEC/AGCM predicted precipitation anomalies for the dry monsoon seasons of July to September 1998, 2005 and 2010, respectively, produced in the previous June (i.e. 1 month lead predictions). The comparison of these forecasts with the observed precipitation anomalies shown in Figure 15(d)-(f) reveals that CPTEC/AGCM managed to predict drought conditions, particularly in the western Amazon, where negative precipitation anomalies of more than $100 \mathrm{~mm}$ were observed. In all three events, sea surface temperatures during May were well above climatology in the tropical North Atlantic (Figure 10(b)), and decaying El Niño conditions were observed in the tropical Pacific in 1998 and 2010 (Figure 10(a)). These conditions in the Atlantic and Pacific were the persistent boundary conditions used to force CPTEC/AGCM. The results of Figure 15 show that CPTEC seasonal prediction system was capable of producing drought warning 1 month in advance for the three investigated events, although only 2010 was a real time forecast, while 1998 and 2005 were hindcasts. Such advanced warning is relevant for helping the government and local population make decisions for reducing drought impacts in the Amazon.

\section{Summary and conclusions}

This applied climate study has investigated observed and predicted climate conditions during the three most recent drought events in the Amazon region (1997-1998, 2004-2005 and 2009-2010). The effect of drought conditions on the monsoonlike precipitation regime in the Amazon was discussed. The novel analysis of a century long Negro River level historical 
records applying extreme value theory to monthly mean river levels, putting in perspective those events when river levels fell below a pre-defined low threshold associated to drought events, revealed that the 2010 event was extremely rare, particularly in November. The return period for this event was estimated to be 25.30 years. The prime teleconnection analysis looking into remote effects of sea surface temperatures on Negro River levels highlighted that, particularly during the second half of the year from July to December, the tropical North Atlantic shows a strong negative association with river levels at Manaus. In other words, when unusually warm sea surface temperatures are observed in the tropical North Atlantic, abnormally low river levels are noticed in Manaus. A consistent negative association between sea surface temperatures in the Niño-3.4 region in the equatorial Pacific and Negro River levels has also been identified during February, March and April, indicating that during El Niño (La Niña) events reduced (increased) river levels are most likely to be observed in Manaus. These effects result from large-scale changes in the tropical atmospheric circulation forced by anomalous sea surface temperature patterns, consequently affecting the monsoon-like precipitation regime in the Amazon, as summarized below.

The 1997-1998 and 2009-2010 events presented similar characteristics in the Pacific with El Niño conditions followed by a rapid transition to La Niña conditions. All three events were marked by excessively warm sea surface temperatures in the tropical North Atlantic. Particularly in 2010 sea surface temperatures reached the highest values in history in the tropical North Atlantic, contributing to the establishment of a local meridional Hadley circulation with upward vertical motion over the North Atlantic and downward vertical motion (subsidence) over the Amazon. The combination of El Niño conditions in the Pacific with warm sea surface conditions in the North Atlantic reinforce subsidence conditions in the Amazon, which are unfavourable to the occurrence of precipitation. Even though humidity existed in the tropical atmosphere, cloud formation was inhibited by subsidence. The drought events observed in the Amazon in 1997-1998, 2004-2005 and 2009-2010 were therefore mainly caused by large-scale atmospheric circulation patterns forced by tropical sea surface temperature anomalies in the equatorial Pacific and tropical North Atlantic.

In terms of precipitation pattern time evolution over the Amazon the 1997-1998 event has shown most pronounced drought conditions in early (January to May) 1998 during the traditionally wet monsoon period. For the 2004-2005 and 2009-2010 events drought conditions were most pronounced later in mid-2005 (July to September) and 2010 during the traditionally dry monsoon period. In terms of drought spatial extent over the Amazon, the year 1998 presented the largest area with abnormal precipitation deficit, followed by 2010 and 2005 when drought conditions were restricted to the southwestern Amazon. The monsoon-like precipitation regime was, therefore, most widely affected in 1998 compared to 2010 and 2005.

The effect of biomass burning aerosol in further inhibiting precipitation efficiency over the Amazon region as an additional and secondary possible mechanism contributing to the observed drought patterns in 2005 and 2010 has also been discussed, based on original diagnostics using satellite-derived information. In both years a significant increase in biomass burning aerosol was observed, particularly in August and September during the dry monsoon season. Such an increase can contribute to a reduction in the efficiency of the precipitation formation process. The excessive amount of aerosol acting as cloud condensation nuclei can still result in droplets not large enough to precipitate in the form of rain. Additionally, biomass burning aerosols are efficient in solar radiation absorption and scattering. The smoke reaching the top of the atmosphere absorbs solar radiation and may heat the atmosphere at high levels. The smoke can also reduce the amount of solar radiation reaching the surface. The likely net result of this process is to increase the atmosphere thermodynamic stability. In a more stable atmosphere moist air mass vertical developments near the surface are inhibited, and therefore cloud formation may be reduced. However, a valid argument is that the increase of biomass burning aerosol might be a consequence of late wet monsoon onsets and/or prolonged dry monsoon seasons with possibly negligible effect of aerosol on droughts. There is, therefore, a need for further investigation based on numerical model experiments and site-specific observations in order to confirm the manifestation of this secondary possible mechanism in combination with the primary large-scale forcing (subsidence) mechanism for contributing to drought conditions in the Amazon region.

Finally, the ability of CPTEC/AGCM in predicting precipitation anomalies over the Amazon for dry monsoon seasons of July to September 1998, 2005 and 2010 has been investigated, representing the first assessment of this kind performed with this model. One-month lead predictions, i.e. produced in the previous June, have been examined. The results indicate that CPTEC seasonal prediction system was capable of producing 1 month in advance drought warnings for the three investigated events. Such advanced warnings, with the advent of an operational seasonal forecasting system, are of great practical relevance for helping the government and local population make decisions for reducing drought impacts in the Amazon region.

This research also suggests an increased probability of further drought events in the Amazon region if the mechanisms here highlighted continue to unfold, primarily the manifestation of the positive trend in the North Atlantic sea surface temperatures in association with global warming, leading to strong subsidence in the Amazon region, and also the maintenance of excessive biomass burning in the Amazon region and in central Brazil during the dry monsoon season.

\section{Acknowledgements}

CASC was supported by Conselho Nacional de Desenvolvimento Científico e Tencológico (CNPq) process 306664/ 2010-0. The research leading to these results has received funding from the European Community's Seventh Framework Programme (FP7/2007-2013) under Grant Agreement No 212492: CLARIS LPB. A Europe-South America Network for Climate Change Assessment and Impact Studies in La Plata Basin. We also acknowledge the MODIS mission scientists and associated NASA personnel for the production of the data used in this research effort.

\section{References}

Acker J, Leptoukh G. 2007. Online analysis enhances use of NASA earth science data. EOS, Trans. Am. Geophys. Union 88(2): 14-17.

Ackerman AS, Toon OB, Stevens DE, Heymsfield AJ, Ramanathan V, Welton EJ. 2000. Reduction of tropical cloudiness by soot. Science 288: 1042-1047, DOI: 10.1126/science.288.5468.1042.

Albrecht BA. 1989. Aerosols, cloud microphysics, and fractional cloudiness. Science 245(4923): 1227-1230.

Andreae MO, Rosenfeld D, Artaxo P, Costa AA, Frank GP, Longo KM, Silva-Dias MAF. 2004. Smoking rain clouds over the Amazon. Science 303: 1337-1342. 
Brankovic C, Palmer TN, Ferranti L. 1994. Predictability of seasonal atmospheric variations. J. Clim. 7: 217-237.

Cavalcanti IFA, Marengo JA, Satyamurty P, Nobre CA, Trosnikov I, Bonatti JP, Manzi AO, Tarasova T, Pezzi LP, D'Almeida C, Sampaio G, Castro CC, Sanches MB, Camargo H. 2002. Global climatological features in a simulation using the CPTEC-COLA AGCM. J. Clim. 15: $2965-2988$.

Charney JG, Shukla J. 1981. Predictability of monsoons. In Monsoon Dynamics, Lighthill J, Pearce R (eds). Cambridge University Press: Cambridge, UK; 99-109.

Coles SG. 2001. An Introduction to Statistical Modeling of Extreme Values, Springer Series in Statistics. Springer: London; 224 pp.

Davison AC, Hinkley DV. 1997. Bootstrap Methods and Their Application. Cambridge University Press: Cambridge, UK; 582 pp.

Fan J, Zhang R, Tao WK, Mohr KI. 2008. Effects of aerosol optical properties on deep convective clouds and radiative forcing. J. Geophys. Res. 113(D8): D08209, DOI: 10.1029/2007JD009257.

Feingold G, Jiang H, Harrington JY. 2005. On smoke suppression of clouds in Amazonia. Geophys. Res. Lett. 32: L02804, DOI: 10.1029/2004GL021369.

Hansen J, Sato M, Ruedy R. 1997. Radiative forcing and climate response. J. Geophys. Res. 102: 6831-6864.

Hobbs PV, Reid JS, Kotchenruther RA, Ferek RJ, Weiss R. 1997. Direct radiative forcing by smoke from biomass burning. Science 275: $1776-1778$

Huffman GJ, Adler RF, Bolvin DT, Gu G, Nelkin EJ, Bowman KP, Stocker EF, Wolff DB. 2007. The TRMM multi-satellite precipitation analysis: quasi-global, multi-year, combined-sensor precipitation estimates at fine scale. J. Hydrometeorol. 8: 38-55.

Jones C, Carvalho LMV. 2002. Active and break phases in the South American Monsoon System. J. Clim. 15: 905-914.

Kalnay E, Kanamitsu M, Kistler R, Collins W, Deaven D, Gandin L, Iredell M, Saha S, White G, Wollen J, Zhu Y, Letman A Reynolds R, Chelliah M, Ebisuzaki W, Higgins W, Janowiak J, Moo KC, Ropelewski C, Wang J, Jenne R, Josepf D. 1996. The NCEP/NCAR 40-Year Reanalysis Project. Bull. Am. Meteorol. Soc. 77(3): 437-471.

Kanamitsu M, Ebisuzaki W, Woollen J, Yang S-K, Hnilo JJ, Fiorino MG, Potter GL. 2002. NCEP-DOE AMIP-II Reanalysis (R-2). Bull. Am. Meteorol. Soc. 83: 1631-1643.

Kaufman YJ, Tanre D, Boucher O. 2002. A satellite view of aerosols in the climate system. Nature 419: 215-223, DOI 10.1038/nature01091.

Khain AP, Rosenfeld D, Pokrovsky P. 2005. Aerosol impact on the dynamics and microphysics of convective clouds. Q. J. R. Meteorl. Soc. 131: 2639-2663.

Koren I, Kaufman YJ, Remer LA, Martins JV. 2004. Measurements of the effect of Amazon smoke on inhibition of cloud formation. Science 303: 1342-1344.

Koren I, Remer L, Longo K. 2007. Reversal of trend of biomass burning in the Amazon. Geophys. Res. Lett. 34: L20404, DOI: 101029/2007GL031530.

Kuo HL. 1974. Further studies of the parameterization of the influence of cumulus convection on a large-scale flow. J. Atmos. Sci. 31 $1232-1240$.

Lau KM, Kim MK, Kim KM. 2006. Asian summer monsoon anomalies induced by aerosol direct forcing: the role of the Tibetan Plateau. Clim. Dyn. 26: 855-864, DOI: 101007/s00382-006-0114-z.

Lewis SL, Brando PM, Phillips OL, van der Heijden GMF, Nepstad D. 2011. The 2010 Amazon drought. Science 331: 554.

Lynn B, Khain A, Rosenfeld D, Woodley WL. 2007. Effects of aerosols on precipitation from orographic clouds. J. Geophys. Res. 112: D10225, DOI: 101029/2006JD007537.

Marengo JA, Cavalcanti IFA, Satyamurty P, Trosnikov I, Nobre CA, Bonatti JP, Camargo H, Sampaio G, Sanches MB, Manzi AO, Castro CAC, D'almeida C, Pezzi LP, Candido L. 2003. Assessment of regional seasonal rainfall predictability using the CPTEC/COLA atmospheric GCM. Clim. Dyn. 21: 459-475.

Marengo JA, Liebmann B, Kousky VE, Filizola NP, Wainer IC. 2001. Onset and end of the rainy season in the Brazilian Amazon basin. J. Clim. 14: 833-852.

Marengo JA, Nobre CA, Tomasella J, Oyama MD, Oliveira GS, Oliveria R, Camargo H, Alves LM, Brown IF. 2008. The drought of Amazonia in 2005. J. Clim. 21: 495-516.

Marengo JA, Tomasella J, Alves LM, Soares WR, Rodriguez DA. 2011. The drought of 2010 in the context of historical droughts in the Amazon region. Geophys. Res. Lett. 38: L12703, DOI: 10.1029/2011GL047436.

Martins JA, Silva Dias MAF,Goncalves FLT. 2009. Impact of biomass burning aerosols on precipitation in the Amazon: a modeling case study. J. Geophys. Res. 114: D02207, DOI: 101029/ 2007JD009587.

Miller RL, Tegen I, Perlwitz J. 2004. Surface radiative forcing by soil dust aerosols and the hydrologic cycle. J. Geophys. Res. 109(D4): D04203, DOI: 101029/2003JD004085.

Penner JE, Dickinson RE, O'Neill CA. 1992. Effects of aerosol from biomass burning on the global radiation budget. Science 256: $1432-1434$

Ramanathan V, Carmichael G. 2008. Global and regional climate changes due to black carbon. Nat. Geosci. 1: 221-227.

Ramanathan V, Crutzen PJ, Kiehl JT, Rosenfeld D. 2001. Aerosols, climate, and the hydrological cycle. Science 294: 2119-2124.

Rayner NA, Parker DE, Horton EB, Folland CK, Alexander LV, Rowell DP, Kent EC, Kaplan A. 2003. Global analyses of sea surface temperature, sea ice, and night marine air temperature since the late nineteenth century. J. Geophys. Res. 108(D14): 4407, DOI: 101029/2002JD002670.

Remer LA, Kaufman YJ, Tanre D, Mattoo S, Chu DA, Martins JV, Li RR, Ichoku C, Levy RC, Kleidman RG, Eck TF, Vermote E, Holben BN. 2005. The MODIS aerosol algorithm, products and validation. J. Atmos. Sci. 62: 947-973.

Reynolds RW, Rayner NA, Smith TM, Stokes DC, Wang W. 2002. An improved in situ and satellite SST analysis for climate. J. Clim. 15: $1609-1625$.

Rosenfeld D. 1999. TRMM observed first direct evidence of smoke from forest fires inhibiting rainfall Geophys. Res. Lett. 26(20): 3105-3108, DOI: 101029/1999GL006066.

Silva Dias MAF, Rutledge S, Kabat P, Silva Dias PL, Nobre C, Fisch G, Dolman AJ, Zipser E, Garstang M, Manzi AO, Fuentes JD, Rocha HR, Marengo J, Plana-Fattori A, Sa LDA, Alvala RCS, Andreae MO, Artaxo P, Gielow R, Gatti L. 2002. Cloud and rain processes in a biosphere-atmosphere interaction context in the Amazon Region. $J$. Geophys. Res. 107(D20): 8072, DOI: 101029/201JD000335.

Stone RS, Anderson G, Shettle E, Andrews E, Loukachine K, Dutton E, Schaaf C, Roman M III. 2008. Radiative impact of boreal smoke in the Arctic: Observed and modeled. J. Geophys. Res. 113: D14S16, DOI: 101029/2007JD009657.

Twomey S. 1974. Pollution and the planetary albedo. Atmos. Environ. 8: 1251-1256, DOI: 101016/0004-6981(74)90004-3.

Wood R, Bretherton CS. 2006. On the relationship between stratiform low cloud cover and lower tropospheric stability. J. Clim. 19: 6425-6432, DOI: 101175/JCLI39881.

Zhang $\mathrm{Y}, \mathrm{Fu} \mathrm{R}$, Yu H, Dickinson RE, Juarez RN, Chin M, Wang H. 2008. A regional climate model study of how biomass burning aerosol impacts land-atmosphere interactions over the Amazon. J. Geophys. Res. 113: D14S15, DOI: 101029/ 2007JD009449.

Zhang Y, Fu R, Yu H, Qian Y, Dickinson R, Silva Dias MAF, da Silva Dias PL, Fernandes K. 2009. Impact of biomass burning aerosol on the monsoon circulation transition over Amazonia. Geophys. Res. Lett. 36: L10814, DOI: 101029/2009GL037180. 